\title{
XSE
}

Stockholm Environment Institute, Project Report - 2009

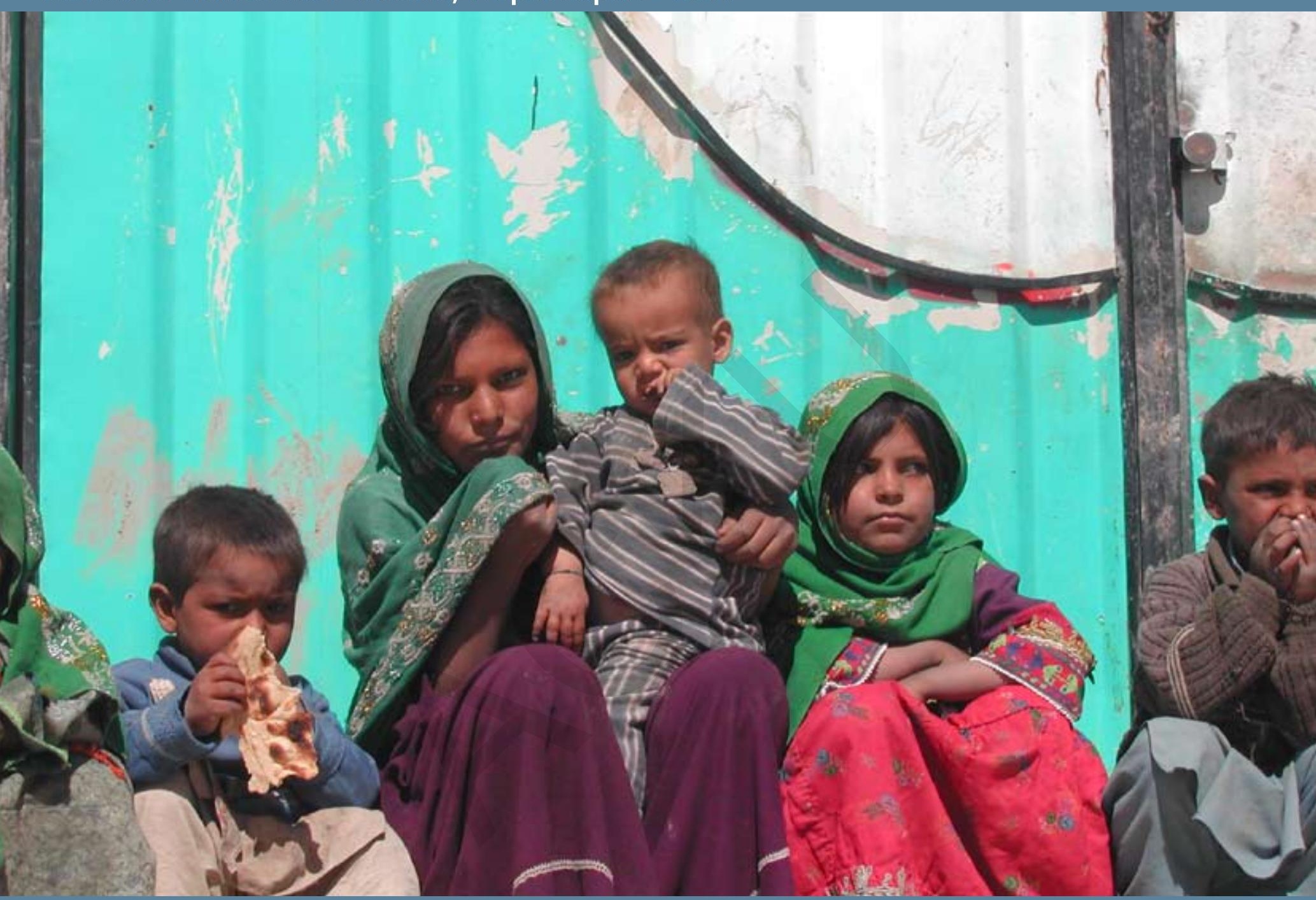

\section{Socio-Economic Impacts of Climate Change in Afghanistan}

A Report to the Department for International Development

Matthew Savage, Bill Dougherty, Mohammed Hamza, Ruth Butterfield, Sukaina Bharwani

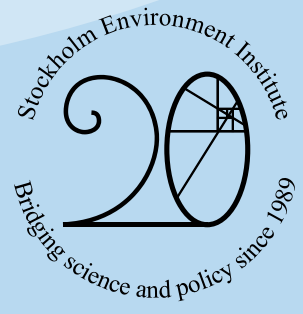




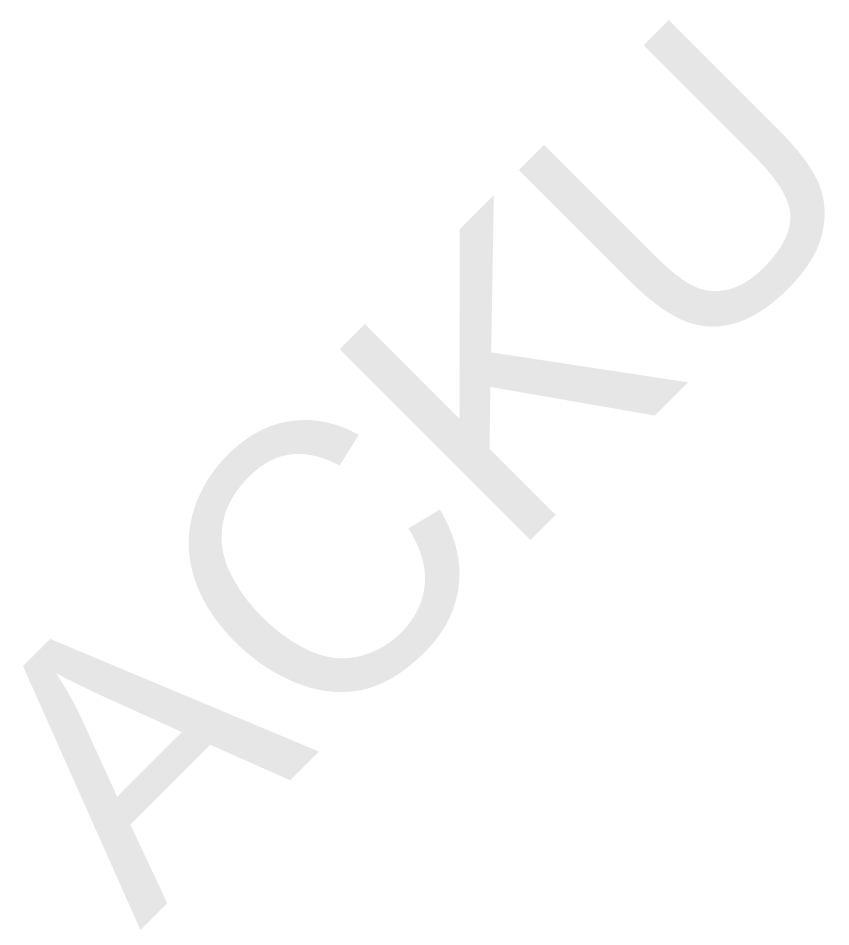


Socio-Economic Impacts of Climate Change in Afghanistan

A Report to the Department for International Development

Matthew Savage, Bill Dougherty, Mohammed Hamza,

Ruth Butterfield, Sukaina Bharwani 
Stockholm Environment Institute

Kräftriket 2B

SE 10691 Stockholm

Sweden

Tel: +4686747070

Fax: +4686747020

Web: www.sei-international.org

Head of Communications: Robert Watt

Publications Manager: Erik Willis

Layout: Richard Clay

Cover Photo: (C) EC/ECHO Kabul

This publication may be reproduced in whole or in part and in any form for educational or non-profit purposes, without special permission from the copyright holder(s) provided acknowledgement of the source is made. No use of this publication may be made for resale or other commercial purpose, without the written permission of the copyright holder(s).

Copyright (c) December 2009

by Stockholm Environment Institute

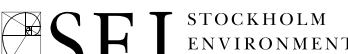

¿SEI 


\section{CONTENTS}

Executive summary $v$

1 Introduction 1

2 Climatic Trends 1960-2008 2

Key message 2

Historic climate trends - 1960-2003 2

3 Climate projections 2008-2090 4

Key message 4

4 Climatic hazards 9

Key message 9

Key climatic hazards 9

5 Sectoral impacts $\quad 13$

Impacts on agriculture and irrigation 14

$\begin{array}{ll}\text { Impacts on water resources } & 16\end{array}$

$\begin{array}{ll}\text { Impacts upon livelihoods and social protection } & 17\end{array}$

$\begin{array}{lr}\text { Impacts on the energy sector } & 18\end{array}$

6 Climate assessment of national development strategies 23

National agriculture and rural development strategy 23

$\begin{array}{ll}\text { National social protection strategy } & 23\end{array}$

7 Adaptation and climate risk screening for development 25

Adaptation classifications 25

Adaptation screening 25

$\begin{array}{ll}\text { Integrating ongoing adaptation activities } & 26\end{array}$

$\begin{array}{ll}\text { Climate risk screening process } & 26\end{array}$

$\begin{array}{ll}\text { Bibliography } & 30\end{array}$ 


$$
p^{c+t^{\nu}}
$$




\section{EXECUTIVE SUMMARY}

\section{Overview}

- This summary provides the key findings of a DFID funded scoping study on the socioeconomic impacts of climate change in Afghanistan. The report has been written to feed into the National Adaptation Programme of Action (NAPA) process managed by the Afghan National Environmental Protection Agency (NEPA) and UNEP. It presents a concise analysis for policy markers and key constituencies within Afghanistan looking to integrate climate change into development planning.

- The main body of the report sets out the results of climate modelling work recently undertaken in the UK by the University of Oxford/Tyndall Centre for DFID and UNDP. It assesses these potential climatic risks and their implications for three policy areas: Agriculture, Social Protection and Energy \& Water. The report then reviews the suitability of current government policy frameworks to address such challenges in terms of mitigation and adaptation. It then sets out an approach to incorporate climate risk management and adaptation into development policy formulation.

- Afghanistan presents a number of specific challenges in terms of climate change assessment. Climate projections for Afghanistan require significant refinement due to the lack of availability of reliable historic meteorological records. Complex topography in Afghanistan also means that local variations in response to global warming, particularly precipitation, are likely to be large and many areas may vary from the regional trends. In addition, sporadic and poor quality socio-economic data make econometric modelling or robust cost/benefit analysis of adaptation and mitigation policy extremely difficult. Poor national security also restricts the ability to undertake structured fieldwork to assess potential mitigation and adaptation options.

\section{Current climatic trends}

- Afghanistan is a mountainous and very dry country located in the arid sub-tropics at $37^{\circ}$ north of the equator. Afghanistan has an arid and semi-arid continental climate with cold winters and hot summers. The lowland plains in the south of Afghanistan experience extreme seasonal variations in temperature, with average summer $(\mathrm{JJA})^{1}$ temperatures exceeding $33^{\circ} \mathrm{C}$ and mean winter (DJF) temperatures of around $10^{\circ} \mathrm{C}$. Much of the country is at very high altitude and experiences much lower temperatures all year round, with average summer temperatures not exceeding $15^{\circ} \mathrm{C}$, and winter temperatures below zero in the highest regions.

- Afghanistan is currently suffering the most severe drought in living memory. The country is characterised by large areas with little to no precipitation; that which does occur falls mostly as snow on high mountains from winter storms (of Mediterranean origin) between November and April with peaks in February/March. The snow season varies considerably with elevation. The Asian summer monsoon system helps to keep rainfall low over Afghanistan. Dust storms are a significant part of the climate system associated with northerly winds in warm months.

- Despite the absence of good long term climatic records, available data and trends from neighbouring countries indicate that mean annual temperature has increased by $0.6^{\circ} \mathrm{C}$ since 1960 , at an average rate of around $0.13^{\circ} \mathrm{C}$ per decade. Increases have been most pronounced during the autumn (SON), with increases at an average rate of $0.29^{\circ} \mathrm{C}$ per decade and a significant increase in the number of exceptionally hot days and nights.

- Changes in precipitation regimes tend to vary more between regions than temperature. Mean rainfall over Afghanistan has decreased slightly (at an average rate of $0.5 \mathrm{~mm}$ per month (or 2 per cent per decade) since 1960 . This is mainly due to decreases of around $2.7 \mathrm{~mm}$ per month $(6.6$ per cent per decade) in spring (MAM) rainfall. The proportion of rainfall that occurs in heavy events has not changed with any consistent trend since 1960 .

1 Climate modeling tends to divide the year into 4 temporal divisions. For the purposes of this report the following seasonal breakdown is used MAM - March April May (Spring); JJA - June, July, August (Summer); SON - September, October, November (Autumn); DJF December, January, February (Winter). Climate Projections taken from modelling undertaken by the University of Oxford for UNDP and DFID in 2008. 


\section{Climate Projections}

\section{Changes in Temperature}

- Current models indicate significant warming across all regions of Afghanistan with average predicted increases in temperature of between $2^{\circ} \mathrm{C}$ and $6.2^{\circ} \mathrm{C}$ by 2090 s dependent on global emissions scenarios. Warming is most rapid in spring/summer with this trend being marked in the north and the central plains of Afghanistan. These increases are also consistent with the broad regional observed temperature trends in Central Asia. All projections indicate substantial increases in the frequency of days and nights that are considered 'hot' in current climate, especially during summer months.

- Up to 2030s, the amount of warming is not sensitive to global emission scenarios. The mean annual temperature is projected to increase by 1.4 to $4.0^{\circ} \mathrm{C}$ by the $2060 \mathrm{~s}$, compared to $1970-1999$ averages.

- By 2090, the range of projections by the 2090s under any one emissions scenario is around 1.5 to $2.5^{\circ} \mathrm{C}$. The range of potential annual temperature increases is noticeably influenced by global emission scenarios.

\section{Changes in Precipitation}

- In the short term, average rainfall is projected to show a small increase, although by little more than about $10-20 \mathrm{~mm}$. Mean annual rainfall changes in the 2090s show conditions are generally drier (by between 10-40 mm) over much of Afghanistan. Much of the drying is due to decreases in spring rainfall (MAM). Winters are expected to be significantly drier in the South. Projections of mean annual rainfall from different models are broadly consistent in indicating decreases.

\section{Climatic Hazards}

The climate models suggest that Afghanistan will be confronted by a range of new and increased climatic hazards. The most likely adverse impacts of climate change in Afghanistan are drought related, including associated dynamics of desertification and land degradation. Drought is likely to be regarded as the norm by 2030 , rather than as a temporary or cyclical event.

Floods due to untimely rainfall and a general increase in temperature are of secondary importance. However, their impacts may by amplified due to more rapid spring snow melt as a result of higher temperatures, combined with the downstream effects of land degradation, loss of vegetative cover and land mismanagement. Nearly all of Afghanistan's 34 provinces have been hit with one or more natural disasters, including flooding, landslides, drought, and extreme heat and freezing weather as shown in figure 1.5.

\section{Sectoral impacts of climate change}

The worsening climatic conditions in Afghanistan will continue to impact upon socio-economic development of Afghanistan, creating stresses for specific vulnerable

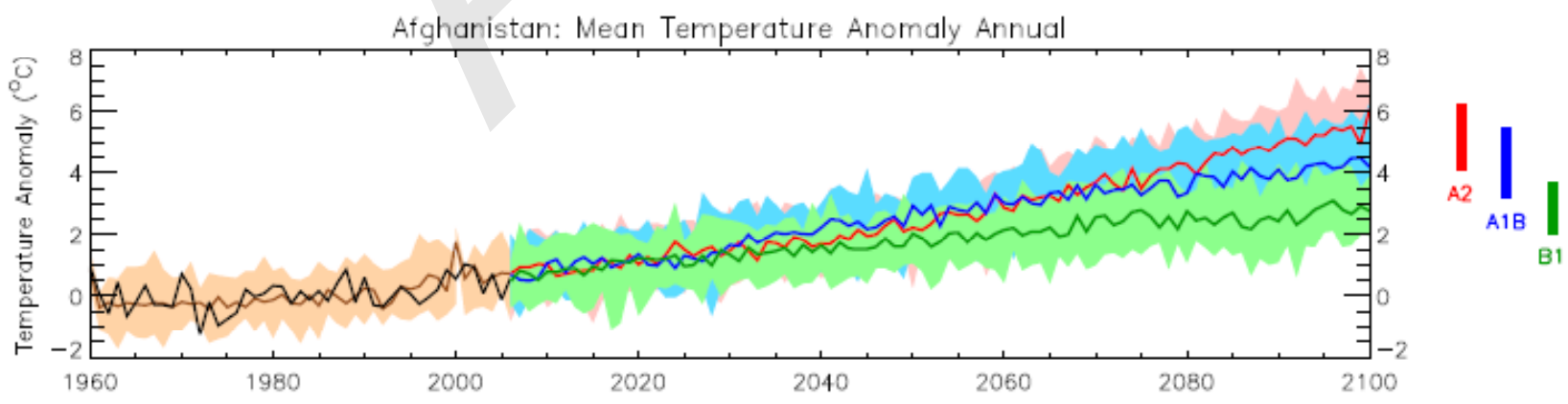

Figure 1.1: Change in temperature to 2100 under 3 emissions scenarios (vs. 197099 average)

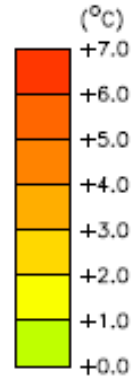



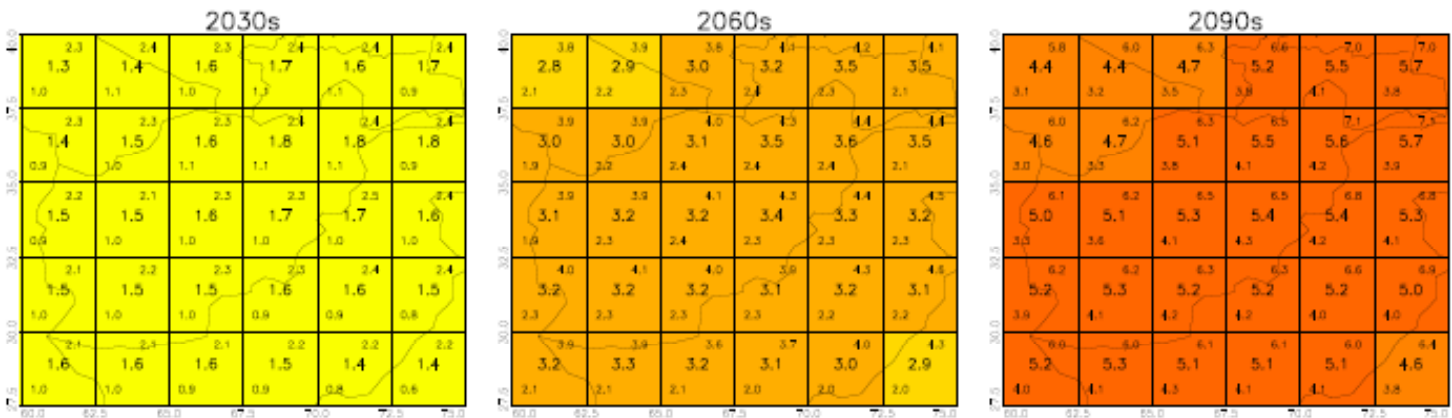

Figure 1.2: Spatial projections for temperature change under SRES A2 scenario (2030, 2060, 2090)

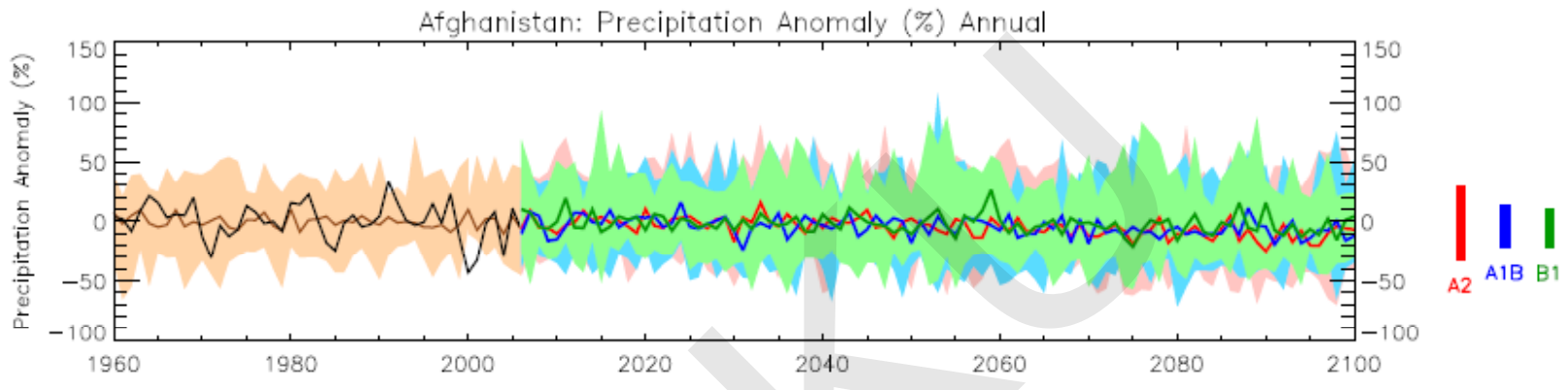

Figure 1.3: Change in temperature to 2100 under 3 emissions scenarios (vs.

(\% change) 1970-99 average)
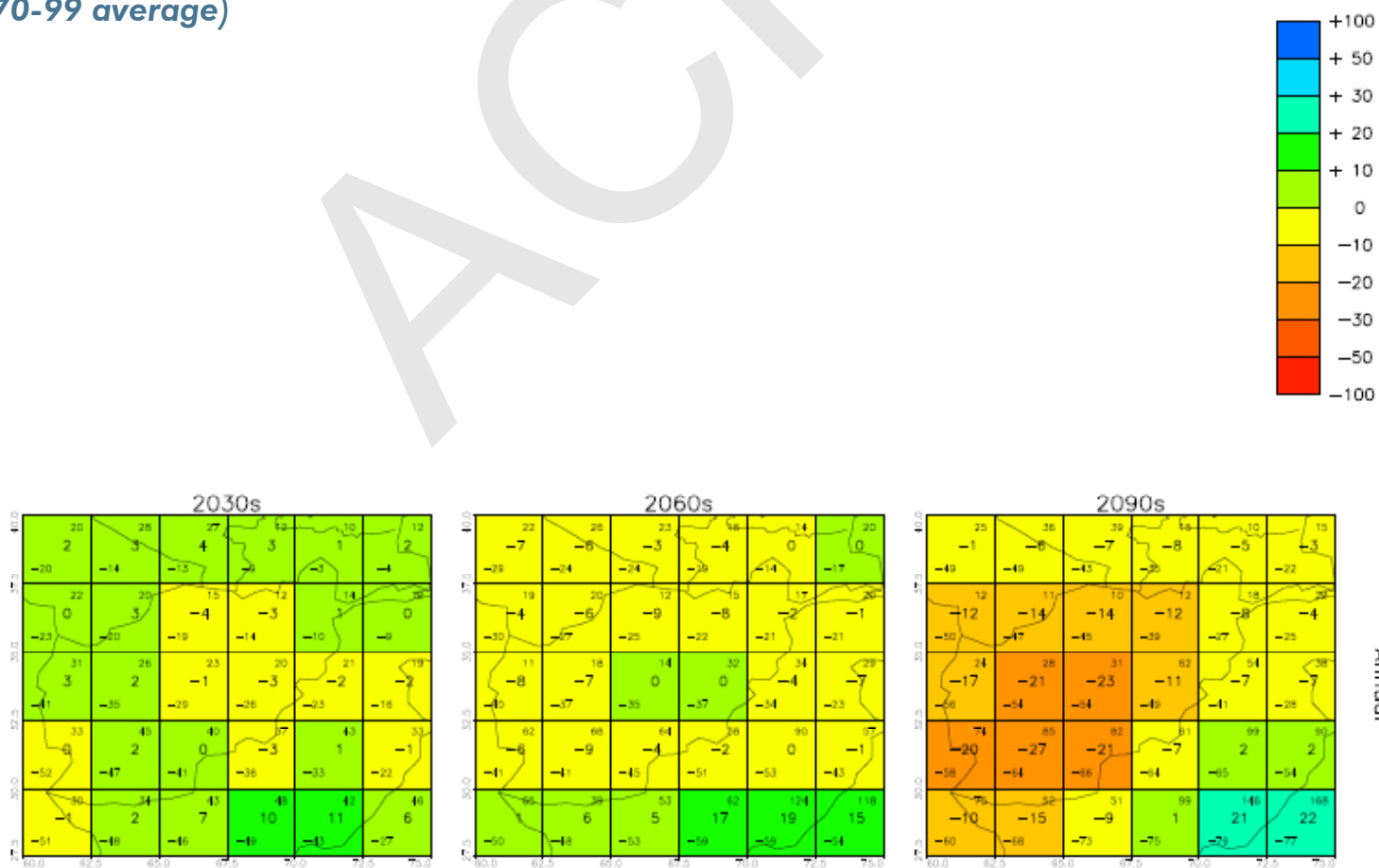

疍

Figure 1.4: Spatial projections for per cent rainfall change under SRES A2 scenario $(2030,2060$, 2090) 


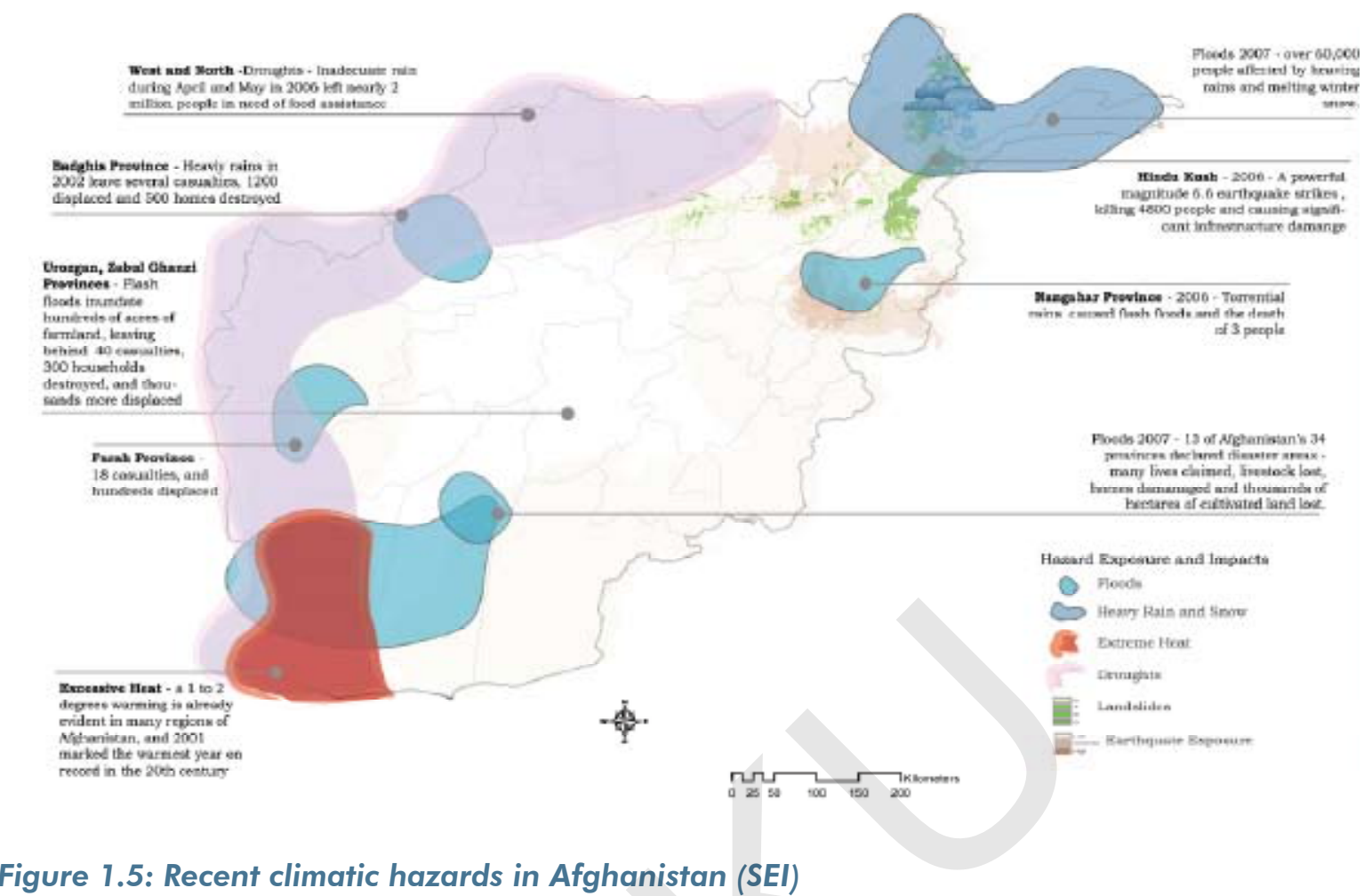

groups. Agriculture and water resources management are likely to be severely impacted by changes in climate.

Agriculture: The vulnerability of the agricultural sector to increased temperatures and changes in rainfall patterns and snow melt is high. Increased soil evaporation, reduced river flow from earlier snow melt, and less frequent rain during peak cultivation seasons will impact upon agricultural productivity and crop choice availability. Crop failure due to water shortages and the amount of potentially productive land left uncultivated will likely both increase. More water intensive staple crops will become less attractive to farmers, with a likely increase in the attractiveness of those that are more drought hardy, including opium poppy. By 2060, large parts of the agricultural economy are likely to have become marginal without significant investment in water management and irrigation. The existing irrigation system is operating at a low efficiency rate of about 25 per cent, which indicates that there is considerable scope for reducing wastage of water.

Social Development: The poor are most vulnerable to the effects of climate change in Afghanistan. Climate change is likely to compound existing food security issues and impact heavily upon those dependent on the agricultural economy. The distributional effects are more likely to fall upon women and children,

and upon those involved in subsistence agriculture or pastoralism. A large proportion of the Afghan population live just above the poverty line climatic shocks have the potential to tip a large percentage of population into poverty. Impacts on human health, such as increased prevalence of disease, affect the amount of labour available for agriculture and other non-farm rural economic activities. The effects of environmental degradation and lower agricultural output reduce the availability of animal feed, and the funds available for livestock husbandry. Climate change will undermine Afghanistan's ability to achieve its goals in reducing malaria morbidity and mortality by 50 per cent -80 per cent within 5 years.

Water Resources: Uncoordinated water management policies can reduce adaptive capacity and increase vulnerability. The cumulative effects of more frequent and intense droughts on reservoirs and groundwater could threaten the water supply of entire communities in the most arid regions of Afghanistan, leading to a range of humanitarian crises, including disease, population displacement and conflict. Rises in winter and spring temperatures will lead to more rapid and earlier snow melt, creating risk of flash flooding. The impact of increasingly frequent flash floods is exacerbated by drought, which has the effect of hardening soils and reducing their permeability. The lack of water availability will increase pressure on Afghanistan and 
surrounding states to claim the greatest possible share of regional water sources in the longer term. Water disputes have plagued the central Asian region for years and will likely continue if climate change increases water scarcity in the region. Efforts by Afghanistan to increase its share of water use in the region may have regional implications.

Energy: From a mitigation perspective, greenhouse gas emissions in absolute and per capita terms are extremely low in Afghanistan (0.5 tons $\mathrm{CO}_{2} \mathrm{e}$ ) and mitigation is not a short term priority, especially given that a significant proportion of electricity is generated from both indigenous and imported low-carbon hydropower. Climatic impacts are most likely to be felt in hydro-electricity production, although large thermal power plant and transmission infrastructure are also susceptible to flash flooding and heat stress. Changes in precipitation, ice pack and snow melt patterns, combined with climate change-related land use change (devegetation and increased irrigation) can impact upon the variability and availability of water flow. Smaller hydropower plants (SHP) are particularly vulnerable. Monthly discharge at many lowland hydro plants is already declining, partly due to increased competition for water use from upstream irrigation. Expected impacts of climate change are likely to result in stronger flow peaks in winter (due to higher precipitation and earlier snow melt/deglaciation), and less flow in summer, due to lower precipitation, higher evaporation rates and irrigation draw off.

\section{Suitability of existing policy frameworks}

At present, climate change is not a consideration into the national or sectoral plans of the Government of Afghanistan (GoA), despite it presenting a significant threat to cross sectoral development. The phrase 'climate change' is not mentioned in the 2008 version of the ANDS. There are however several programmatic activities that might be classified as adaptive in a climate change context.

While sectoral plans do provide for programmatic activities that address existing climate change stresses, they do not provide a strategy for dealing with their increased severity and frequency. Nowhere are these stresses analysed in the context of a larger process of change. It is unlikely that existing programs are sufficient in scope and scale to meet the challenges indicated by the climate scenarios.

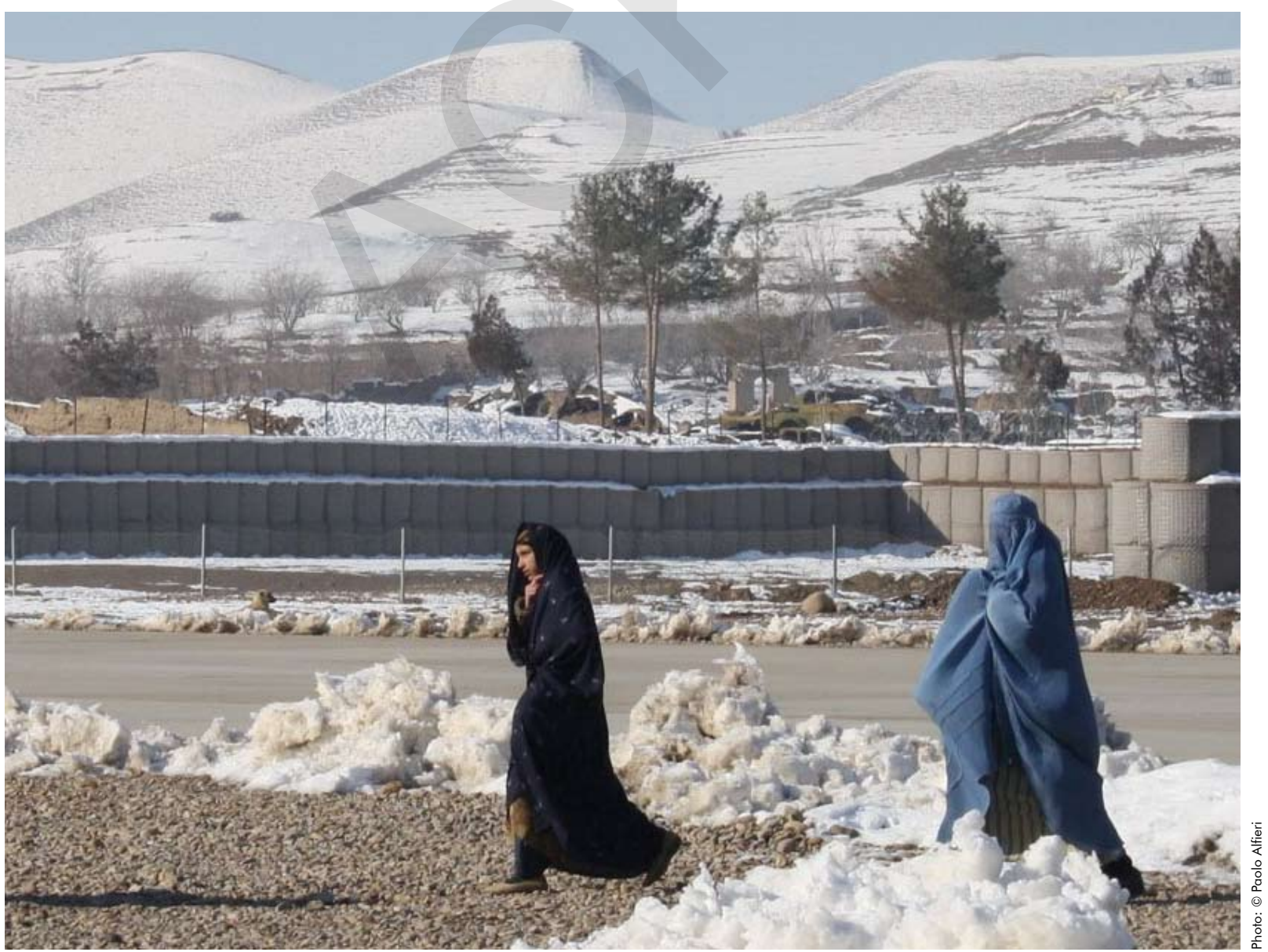




\section{Recommendations}

Further work should be undertaken to improve the resolution and accuracy of regional climate models. In particular, work should be undertaken on cleaning and refining available historic climate data to strengthen the ability to downscale projections to Afghanistan's complex topography. To this extent, work should be undertaken through NEPA to build local modelling capacity with links established to international centres of excellence, such as the Hadley Centre in the UK.

Ministries need to improve the 'climate awareness and resilience' of their development strategies. This will require the application of risk screening within individual sectors. Improved coordination between Ministries will also be required to meet the cross-sectoral challenges of climate change, especially in terms of linkages between water, agriculture and livelihoods. This should be done through the development of a strategic plan that identifies and targets major agricultural, water, protection and rehabilitation projects both ongoing and planned and places then within a high level adaptation strategy.

While mainstreaming climate change in development planning is important, the adaptation challenges facing Afghanistan are very significant in scope and scale. External investment and technical support will be required if these challenges are to be met. The GoA should therefore begin to create costed adaptation investment planning scenarios as a first step towards applying to potential climate adaptation funding mechanisms currently under development by the international community.

Government experts should continue to engage with wider regional planning and development bodies to ensure that best practice climate assessments, adaptation approaches and low carbon development strategies developed elsewhere in Central and South Asia can be applied in Afghanistan.

From a mitigation perspective, encouraging low carbon growth may be a sensible in the medium term and the renewables strategy of the Ministry of Energy and Water (MoEW) is welcome, but climate change considerations should not preclude exploitation of domestic fossil fuel resources to meet demand for power access. Developmental impact should take precedence over emissions considerations in order to build adaptive capacity. The limited reach of regional grids mean that smaller scale off grid renewable energy technologies, such as small hydro, solar PV, solar thermal and wind can play a specific development role in providing access to energy.

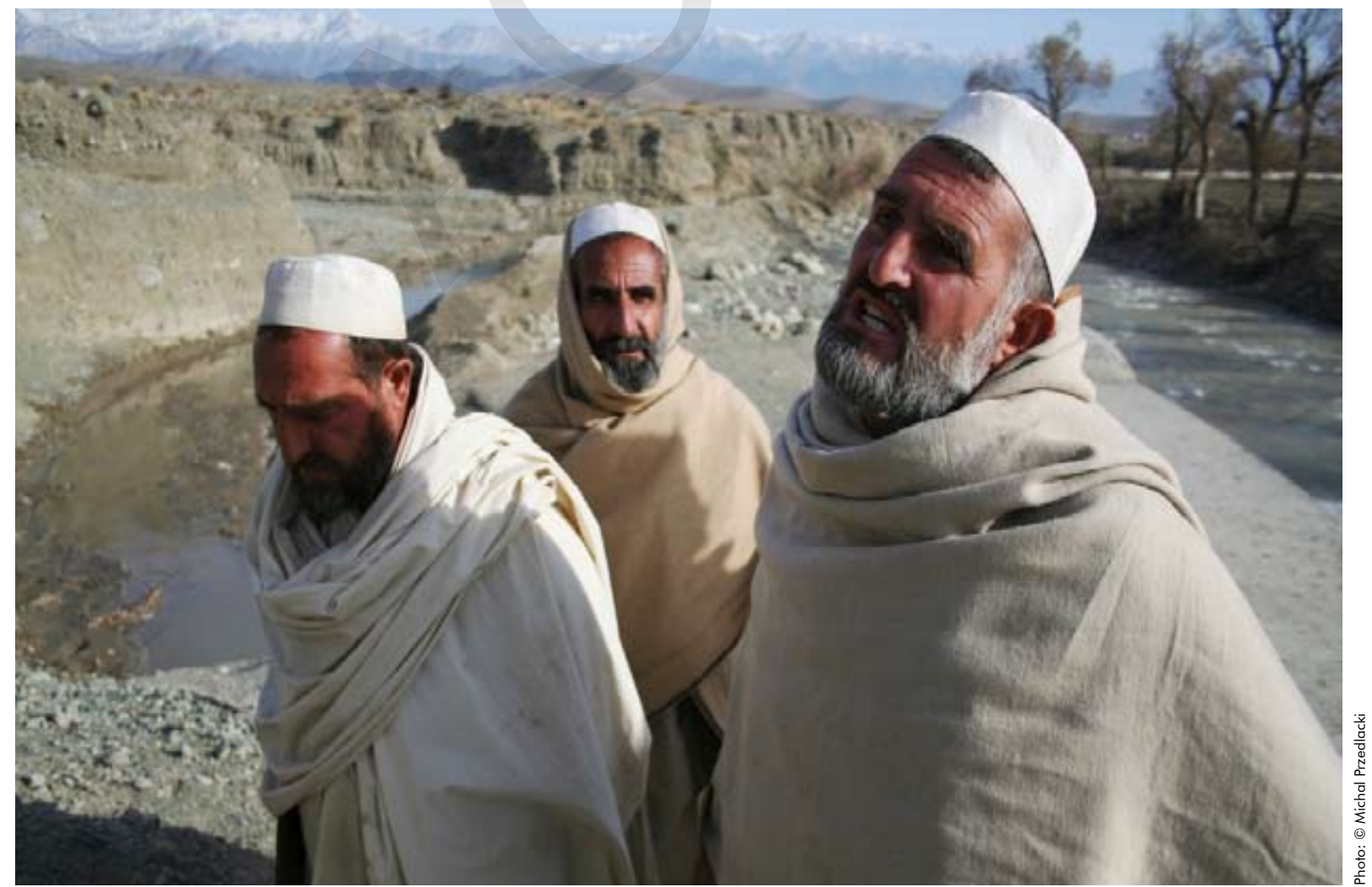




\section{INTRODUCTION}

$T$ his summary provides the key findings of a DFID funded scoping study on the socio-economic impacts of climate change in Afghanistan. The report has been written to feed into the National Adaptation Programme of Action (NAPA) process facilitated by UNEP and the Afghan National Environmental Protection Agency (NEPA). It presents a concise analysis for policy markers and key influencing constituencies within Afghanistan looking to integrate climate change into development planning.

The main body of the report sets out the results of climate modelling work recently undertaken in the UK by the University of Oxford and Tyndall Centre for DFID and UNDP under separate projects. It assesses these potential climatic risks and their implications for three policy areas: Agriculture, Social Protection and Energy \& Water. The report then reviews the suitability of current government policy frameworks to address such challenges in terms of mitigation and adaptation and sets out a methodology to incorporate climate risk management into policy formulation.

Afghanistan presents a number of challenges in terms of climate change assessment. Climate projections for Afghanistan require significant refinement due to the lack of availability of reliable historic meteorological records. Complex topography in Afghanistan also means that local variations in response to global warming, particularly precipitation, are likely to be large and many areas may vary from the regional trends. In addition, sporadic and poor quality socio-economic data make econometric modelling or robust cost/benefit analysis impossible. Poor national security also restricts the ability to undertake structured fieldwork to assess potential mitigation and adaptation options.

The report has been compiled by the Stockholm Environment Institute on the basis of a number of visits to Afghanistan between August-November 2008. These visits have been primarily to meet with government and technical stakeholders in Kabul, but have also included a limited number of trips to sites in the Central region (Kabul, Bamyan Provinces), and Northwest region (Jawzjan, Balkh and Samangan Provinces). Field visits to the South (including Helmand), were not considered feasible due to security concerns.

This report should also be read in the context of wider set of UK-funded studies seeking to analyse the costs and benefits of climate change mitigation and adaptation that take their basis from the Stern Review on the Economics of Climate Change. This report differs from others being prepared for the following reasons.

- GHG mitigation in Afghanistan is not currently relevant issue as per capita emissions are extremely low and are likely to remain so in the short-medium term.

- Sporadic and poor quality socio-economic data make econometric modelling or robust cost/benefit analysis impossible under current circumstances.

- Poor national security circumstances that restricts the ability to undertake structured fieldwork in much of the country with a view to reviewing and assessing adaptation options

- Climate projections for Afghanistan require significant strengthening to date due to a lack of historic meteorological data.

Thanks are due to those who assisted in the preparation of this report, and in particular to Zoe Hensby, Livelihoods Adviser DFID Afghanistan, Gemma Tanner, Deputy Programme Manager/ Environment Adviser, Livelihoods DFID London and the Kabul DFID office who continue to do valuable work in difficult circumstances. 


\section{CLIMATIC TRENDS 1960-2008}

\section{KEY MESSAGE}

Indications are that mean annual temperatures in Afghanistan have increased by $0.6^{\circ} \mathrm{C}$ since 1960 , at an average rate of around $0.13^{\circ} \mathrm{C}$ per decade. Increases have been most pronounced during the autumn, with increases at an average rate of $0.29^{\circ} \mathrm{C}$ per decade. Mean rainfall over the same period has decreased slightly at an average rate of 2 per cent per decade, mainly due to decreases in spring precipitation. This combination of factors has led to a prolonged drought in recent years.

\section{HISTORIC CLIMATE TRENDS - 1960-2003}

Afghanistan is a mountainous and very dry country located in the arid sub-tropics at $37^{\circ}$ north of the equator. Afghanistan has an arid and semi-arid continental climate with cold winters and hot summers. The lowland plains in the south of Afghanistan experience extreme seasonal variations in temperature, with average summer (JJA $)^{2}$ temperatures exceeding $33^{\circ} \mathrm{C}$ and mean winter (DJF) temperatures of around $10^{\circ} \mathrm{C}$. Much of the country is at very high altitude and experiences much lower temperatures all year round, with average summer temperatures not exceeding $15^{\circ} \mathrm{C}$, and winter temperatures below zero in the highest regions.

Afghanistan is currently suffering the most severe drought in living memory. The country is characterised by large areas with little to no precipitation; that which does occur falls mostly as snow on high mountains from winter storms (of Mediterranean origin) between November and April with peaks in February/March. The snow season varies considerably with elevation. The Asian summer monsoon system helps to keep rainfall low over Afghanistan. Dust storms are a significant part of the climate system associated with northerly winds in warm months.

\section{Temperature}

Historic norms and analysis of available data from surrounding countries indicates a trend of increasing mean temperatures, an increase in the number of hot days, and a reduction in cold night temperatures and

2 Climate modeling tends to divide the year into 4 temporal divisions. For the purposes of this report the following seasonal breakdown is used MAM - March April May (Spring); JJA - June, July, August (Summer); SON - September, October, November (Autumn); DJF December, January, February (Winter) cold spells, over recent years. This is consistent with trends in temperature across a broad region of centralsouth Asia.

According to climatic norms used by the World Meteorological Organisation ${ }^{3}$, mean annual temperature has increased by $0.6^{\circ} \mathrm{C}$ since 1960 , at an average rate of around $0.13^{\circ} \mathrm{C}$ per decade. The rate of increase is most rapid in autumn ( $\mathrm{SON})$, with increases at an average rate of $0.29^{\circ} \mathrm{C}$ per decade, and slower in winter (DJF) at a rate $0.11^{\circ} \mathrm{C}$ per decade.

The frequency of hot days and hot nights has increased since 1960 in every season. The average number of 'hot' days per year has increased by 25 (an additional 6.8 per cent of days) between 1960 and 2003. The rate of increase is greatest in autumn when the number of hot days has increased by 3 days per month (an additional 10.3 per cent of days) over this period The average number of 'hot' nights per year has increased by 26 (an additional 6.7 per cent of days) between 1960 and 2003.

\section{Precipitation}

The arid climate of Afghanistan is characterised by large areas with little or no precipitation, but the rainfall that does occur falls primarily as snow on high mountains from winter storms of Mediterranean origin between November and April with peaks in February/March. The Asian summer monsoon system tends to suppress rainfall over Afghanistan. Afghanistan is currently in the grips of the most severe drought in living memory. Rainfall in Afghanistan is very scarce, and mainly only affects the northern highlands, arriving in March and April. Rainfall in the more arid lowlands is rare, and can be very unpredictable. Snowfall is reported as having become more variable.

Changes in precipitation regimes tend to vary more between regions than temperature. In the case of Afghanistan, these can only be assessed from case study commentaries on drought and flood conditions. These include reports of the largest snowfall in a decade (and 80 per cent more than the previous winter) in February

3 Historic climate data is scarce in Afghanistan due to an extended period of political instability, limited meteorological monitoring systems and the large scale loss of data records under the Taliban. Historic data sets from the 1950-1970 are currently being restored by the PEACE project and the SEI team, and may be used to calibrate models in future. 
2005, which began melting in March, bringing flooding to northern, central and western provinces. Floods, although not as severe, were also reported in March 2003. Severe drought conditions prevailed between 1998 and 2001 and are believed to relate partly to La Nina conditions in the Pacific. The droughts were the most severe of the last 50 years.

Mean rainfall over Afghanistan has decreased slightly (at an average rate of $0.5 \mathrm{~mm}$ per month (or 2 per cent per decade) since 1960 . This is mainly due to decreases of around $2.7 \mathrm{~mm}$ per month (6.6 per cent per decade) in spring rainfall, but is offset by small increases in summer and autumn. The proportion of rainfall that occurs in heavy events has not changed with any consistent trend since 1960 . The observed maximum 1 and 5 day rainfalls generally show small decreases in spring, but increase slightly in other seasons.

\section{Data quality and modelling}

There is little or no peer-reviewed literature on current climate trends in Afghanistan. The projections contained in this report were prepared during the course of this project by the University of Oxford and the Tyndall Centre for UNDP and DFID country profiles. They show potential changes in temperature and precipitation under a range of 3 global emissions scenarios known as SRES A1, A2 and B1. ${ }^{4}$ Based on the scenario assumptions, they show a range of potential futures based on the outputs of 15 Global Circulation Models (GCMs).

Although the trends indicated in the report are coherent with wider regional projections for South and Central Asia, some caution needs to be attached. Normally, climate models are evaluated against historic meteorological data and then calibrated to make their historic projections more representative of observed reality. In the case of Afghanistan, this process has been hampered due to a lack of reliable historical data sets, many of which were lost under Taliban rule. Gaps in baseline data relating to the climate and

4 SRES, or the Special Report on Emissions Scenarios was a report prepared by the Intergovernmental Panel on Climate Change (IPCC) for the Third Assessment Report. It set out future emission scenarios to be used for driving global circulation models to develop climate change scenarios. The SRES scenarios were also used for the 4th Assessment Report in 2007. Each scenario family makes different assumptions for future GHG emissions, land use and other driving forces. Assumptions are also made about technology and economic development. The 3 scenarios used in this report are A1b, A2 and B1. For further details see http://www.ipcc. ch/ipccreports/sres/emission/index.htm climate change in Afghanistan are significant. It is our understanding that the historic data used in the climate projections is based on WMO norms, rather than accurate historic records.

The project team have acquired a historic data set from the Ministry of Aviation covering the period from 1950-1970 via the PEACE (Pastoral Engagement, Adaptation and Capacity Enhancement) project which can be used in future to calibrate better the climate models for the country and to provide higher resolution projections. This should be a key area of further support for the international donor community to consider going forward. There is also a need to integrate regional climate change modelling assessments with neighbouring countries in central and south Asia.

Currently, basic climatic data is being collected although only four out of the fifteen fully automated stations are providing reliable data. To this end, it is necessary to improve the reliability of the fourteen additional stations and expand data analysis capacities. Continued conflict throughout the south and south-east of the country furthermore potentially threatens the continuity of data collection in these regions. 


\section{CLIMATE PROJECTIONS 2008-2090}

\section{KEY MESSAGE}

Current models indicate significant warming across all regions of Afghanistan. These increases are consistent with the broad regional observed temperature trends in Central Asia. By 2030s, mean annual temperatures are likely to rise by about $1.4^{\circ} \mathrm{C}$ compared to long-term averages ${ }^{5}$ with little change in overall precipitation. By the 2090s, increases in average temperature are likely to be between $2-6^{\circ} \mathrm{C}$ dependent upon global emissions scenarios. Conditions will become drier, specifically in spring (MAM) with reductions in rainfall of between 10$40 \mathrm{~mm}$ and drier conditions in the south.

\section{Temperature}

Mean annual temperatures are likely to rise by about $1.4^{\circ} \mathrm{C}$ by the 2020 , with slightly lower increases $\left(1.2^{\circ} \mathrm{C}\right)$ between June - August. The largest increases are in the northeast in winter $\left(1.7^{\circ} \mathrm{C}\right)$ and the south in spring $\left(1.7^{\circ} \mathrm{C}\right)$. The amount of warming is not sensitive to the emission scenarios in the 2020s. These increases are consistent with the broad regional observed temperature trends in Central Asia.

By 2090, projected mean annual temperature increases are noticeably influenced by emission scenarios. Annual average temperatures increase by 5.0 (high), 4.4 (medium) and $2.8^{\circ} \mathrm{C}$ (low) scenarios with increases being more marked in the north and the central plains of Afghanistan. Temperature increases are highest in the spring and summer and lowest in winter. Temperature increases by the 2090s in the low emission scenario resemble those of the 2060s for the high emission scenario.

All projections indicate substantial increases in the frequency of days and nights that are considered 'hot' in current climate. Annually, projections indicate that 'hot' days are projected to increase up to 32 per cent of days by the 2090s (compared to a baseline of 10 per cent between 1970-99). All projections indicate decreases in the frequency of days and nights that are considered 'cold' in current climate. These events are expected to become exceedingly rare, occurring on 0.6 per cent of days in the year by the 2090s. 'Cold' days or 'cold' nights are defined as the temperature below which 10 per cent of days or nights are recorded in current climate of that region or season.

\footnotetext{
5 Climate change projections are assessed against a base-
} line of 1970-1999 average

\section{Precipitation}

In the 2030s, rainfall is projected to increase over much of Afghanistan though by little more than about $10-20 \mathrm{~mm}$. The increase is largest in the far northeast $(20-50 \mathrm{~mm})$ and results from increases in spring and winter. Mean annual rainfall changes in the 2090s show conditions are generally drier depending on emissions scenario (-40 $\mathrm{mm}$ high, $-20 \mathrm{~mm}$ medium, $-10 \mathrm{~mm}$ low) over much of Afghanistan. Much of the drying is due to change in spring with decreases arising largely due to reductions in the wet season rainfalls. Autumn is projected to be slightly wetter, especially in the north. Projections of mean annual rainfall from different models in the ensemble are broadly consistent in indicating decreases over this timeframe.

The proportion of total rainfall that falls in heavy events does not show a consistent direction of change, but tends towards positive changes, despite overall decreasing trends in total rainfall. A 'Heavy' event is defined as a daily rainfall total which exceeds the threshold that is exceeded on 5 per cent of rainy days in the current climate of that region and season.

The following tables show the trends in annual and seasonal mean temperature and precipitation for the recent past and projected future. 

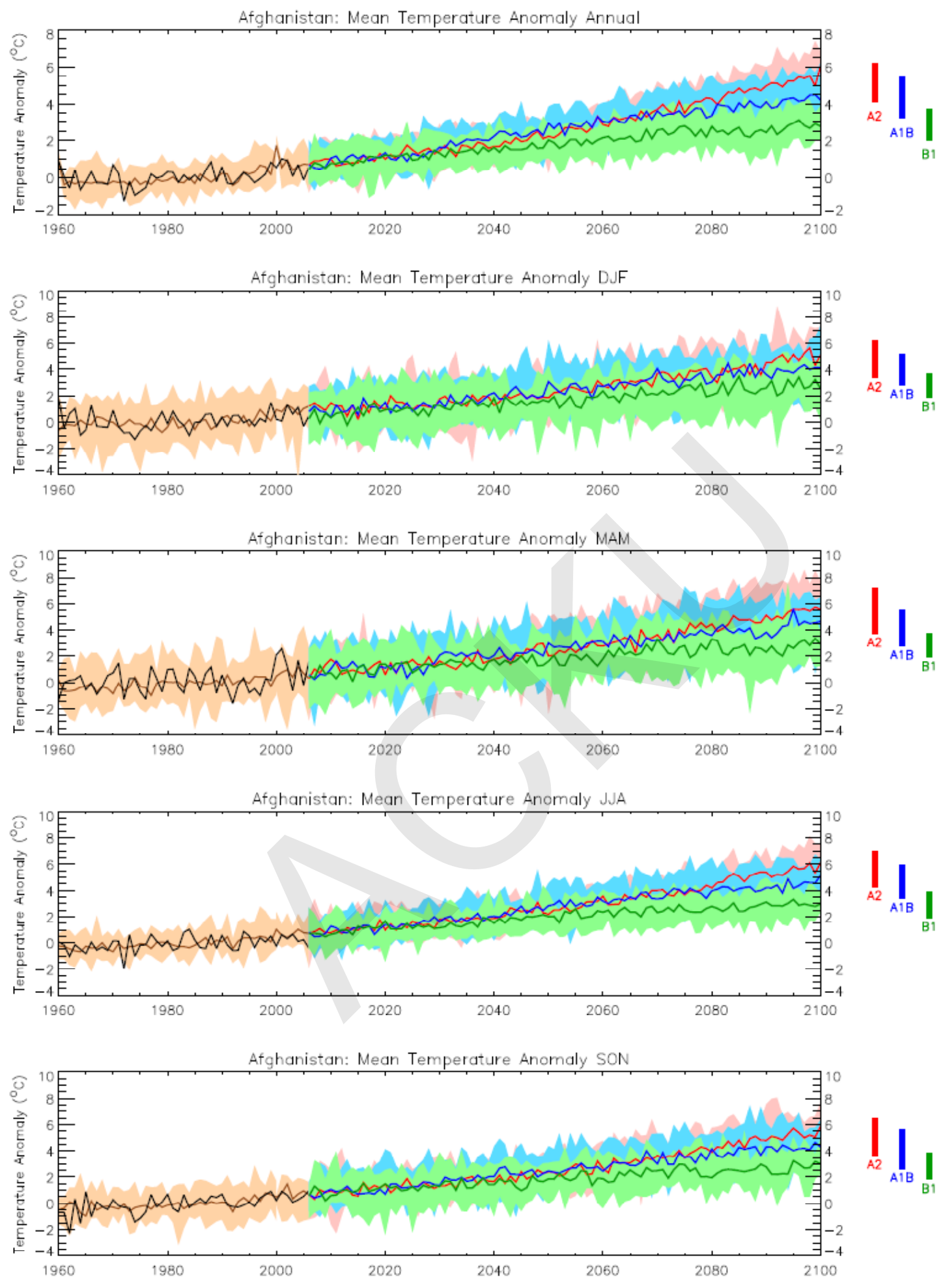

Figure 3.1: Changes in annual temperature $1960-2100$ by season (UNDP) 

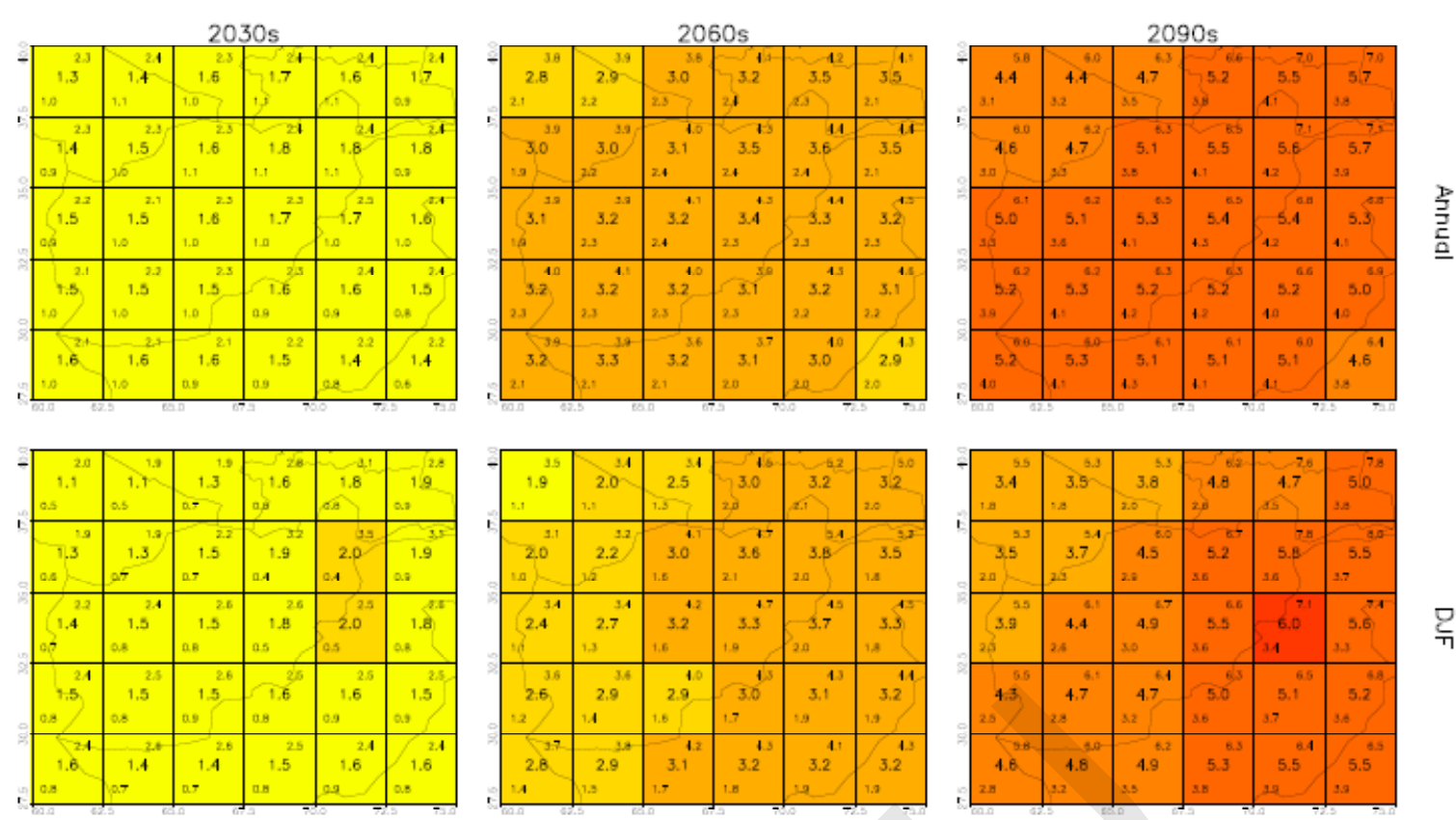

를
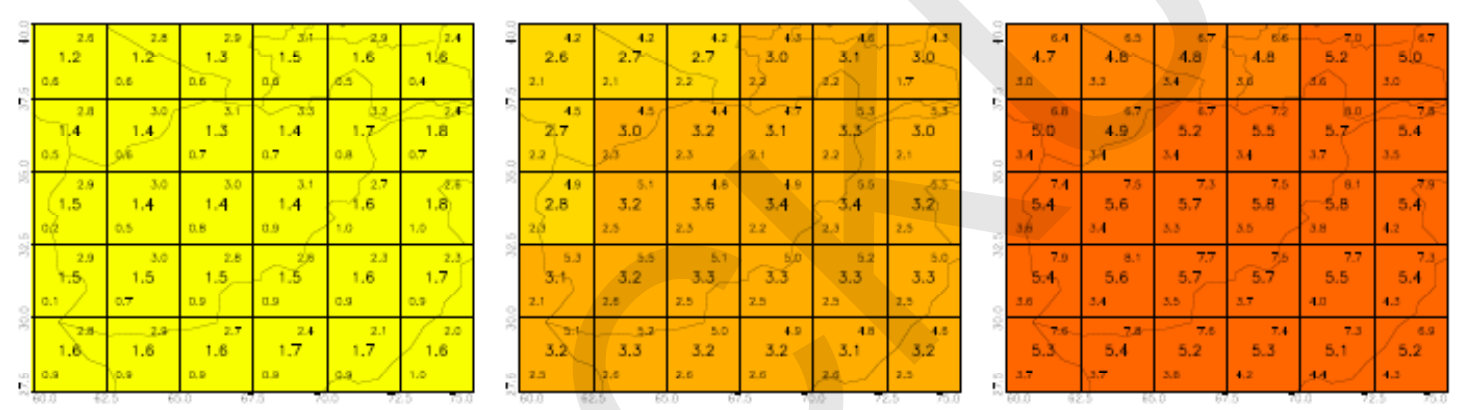

뮦
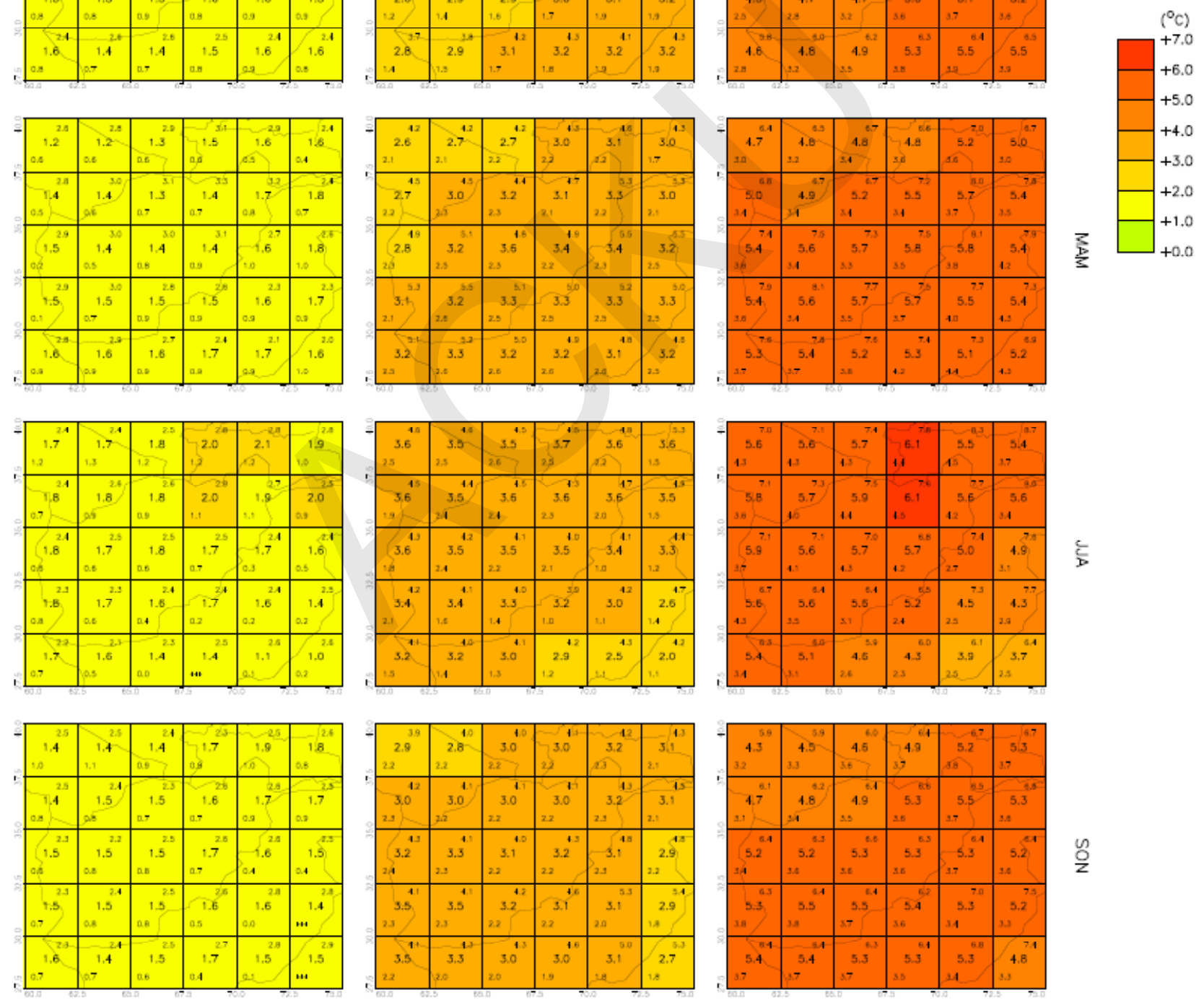

Figure 3.2: Spatial patterns in temperature change under the SRES A2 emissions scenario (UNDP) 

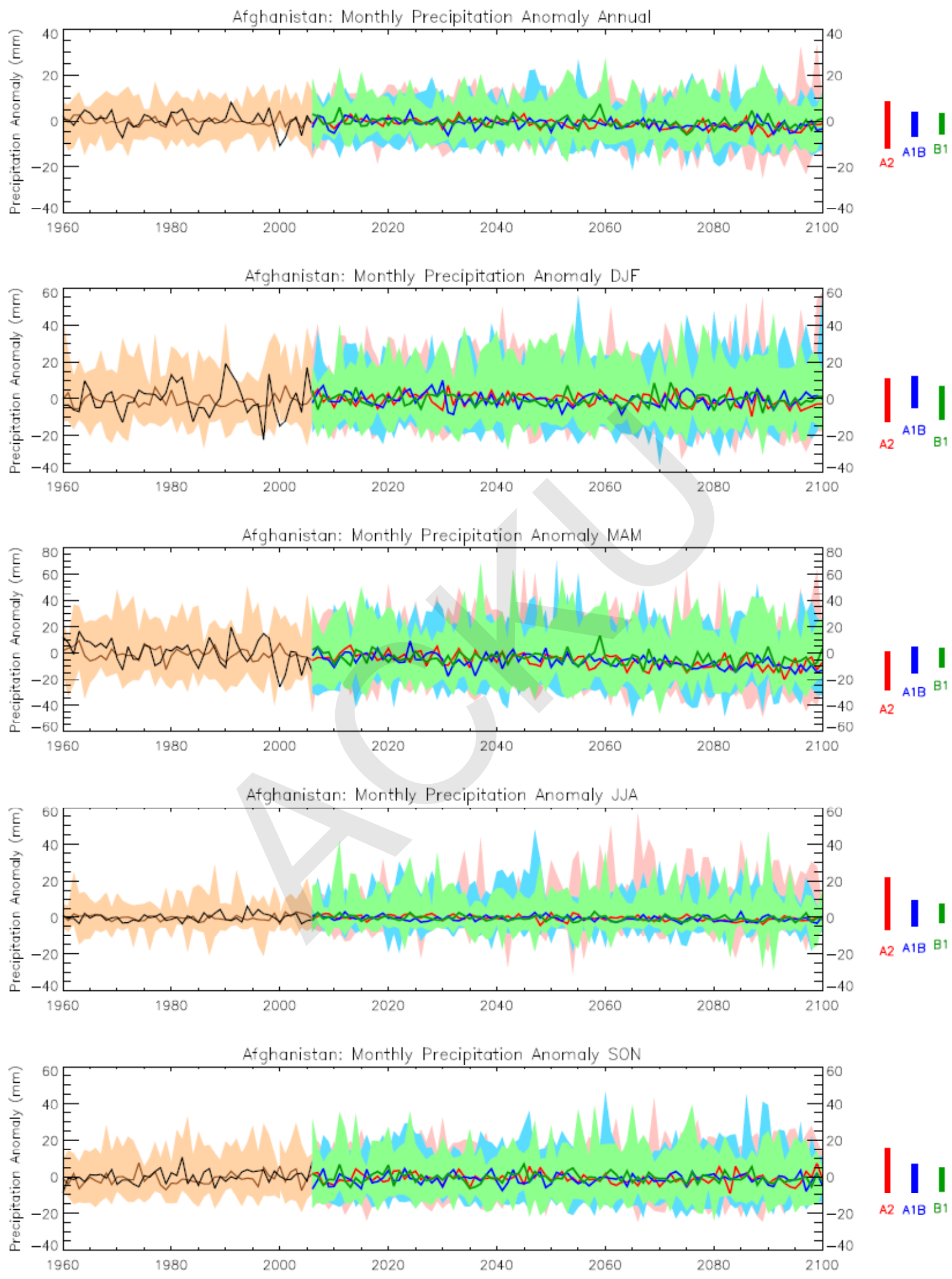

Figure 3.3: Historic and predicted changes in precipitation 1960-2100 under 3 global emission scenarios (UNDP) 

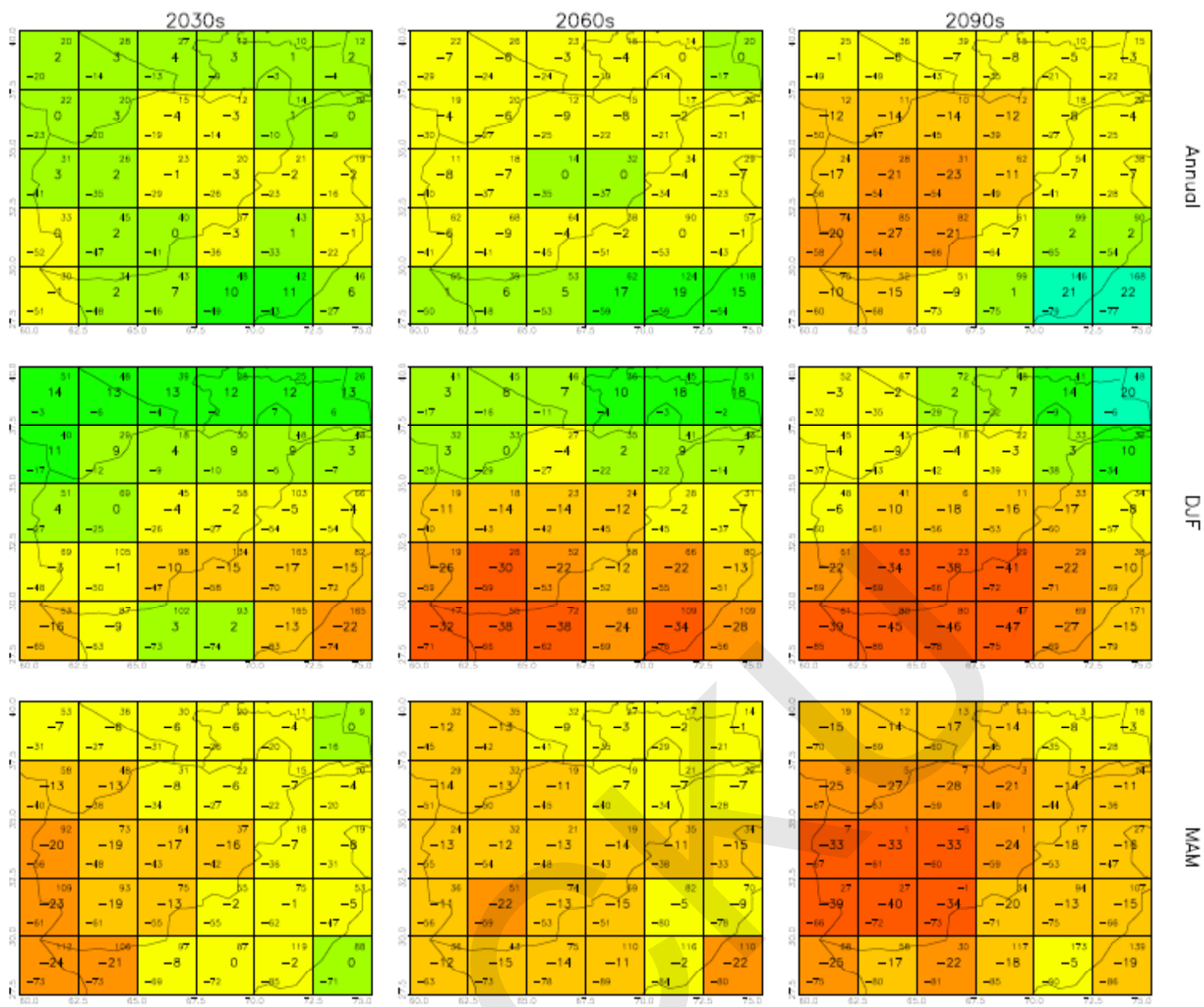

(\% change)
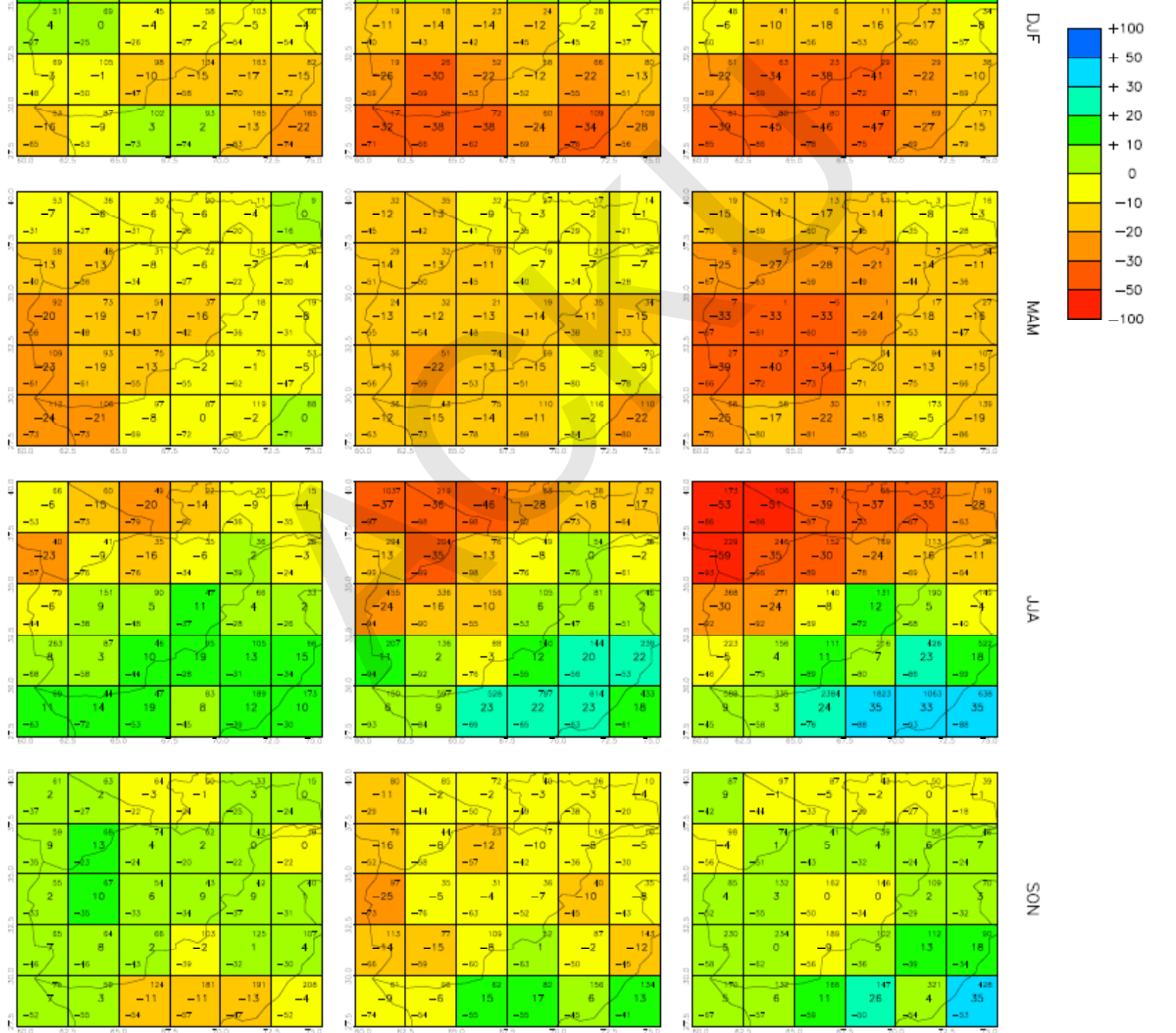

Figure 3.4: Spatial patterns in precipitation changes in per cent terms 1960-2100 under SRES A2 (UNDP) 


\section{CLIMATIC HAZARDS}

\section{KEY MESSAGE}

Climate projections suggest that Afghanistan will be confronted by a range of increased climatic hazards. The most likely adverse impacts of climate change in Afghanistan are drought related, including associated dynamics of desertification and land degradation. Drought is likely to be regarded as the norm by 2030, rather than as a temporary or cyclical event. Floods due to untimely rainfall and a general increase in temperature are currently considered of secondary importance. However, their impacts will likely be amplified by more rapid spring snow melt combined with the downstream effects of land degradation, loss of vegetative cover and land mismanagement.

\section{KEY CLIMATIC HAZARDS}

Climate projections indicate a range of new and increased climatic hazards for Afghanistan. The most likely adverse impacts of climate change in Afghanistan are drought related, including the associated dynamics of desertification and land degradation. Floods due to untimely rainfall and a general increase in temperature are of secondary importance, but are both exacerbated by and exacerbate the adverse impacts of drought. Cumulative effects of more frequent and intense droughts on reservoirs and groundwater could threaten the water supply of entire communities in the most arid regions of Afghanistan, leading to a range of humanitarian crises, including disease, population displacement and conflict. Figure 4.1 provides an overview of the key climatic hazards in Afghanistan, as analysed by the NAPA process, together with their scope and impact:

These climatic hazards have impacts across a range of sectors. Again, this has been well documented during the NAPA process and the analysis is presented below in figure 4.2 .

Climate change will compound existing climatic stresses that the Afghanistan has experienced over the last decade. Nearly all of Afghanistan's 34 provinces have been hit with one or more natural disasters, including flooding, landslides, drought, and extreme heat and freezing weather as shown in figure 4.3.

Water shortages, from droughts and changes in snowmelt will increase pressure on Afghanistan to claim the greatest possible share of regional water sources in the medium term. Existing water disputes will likely continue if climate change furthers water scarcity in the region. Any efforts by Afghanistan to increase its share of water use in the region may have regional security or diplomatic implications.

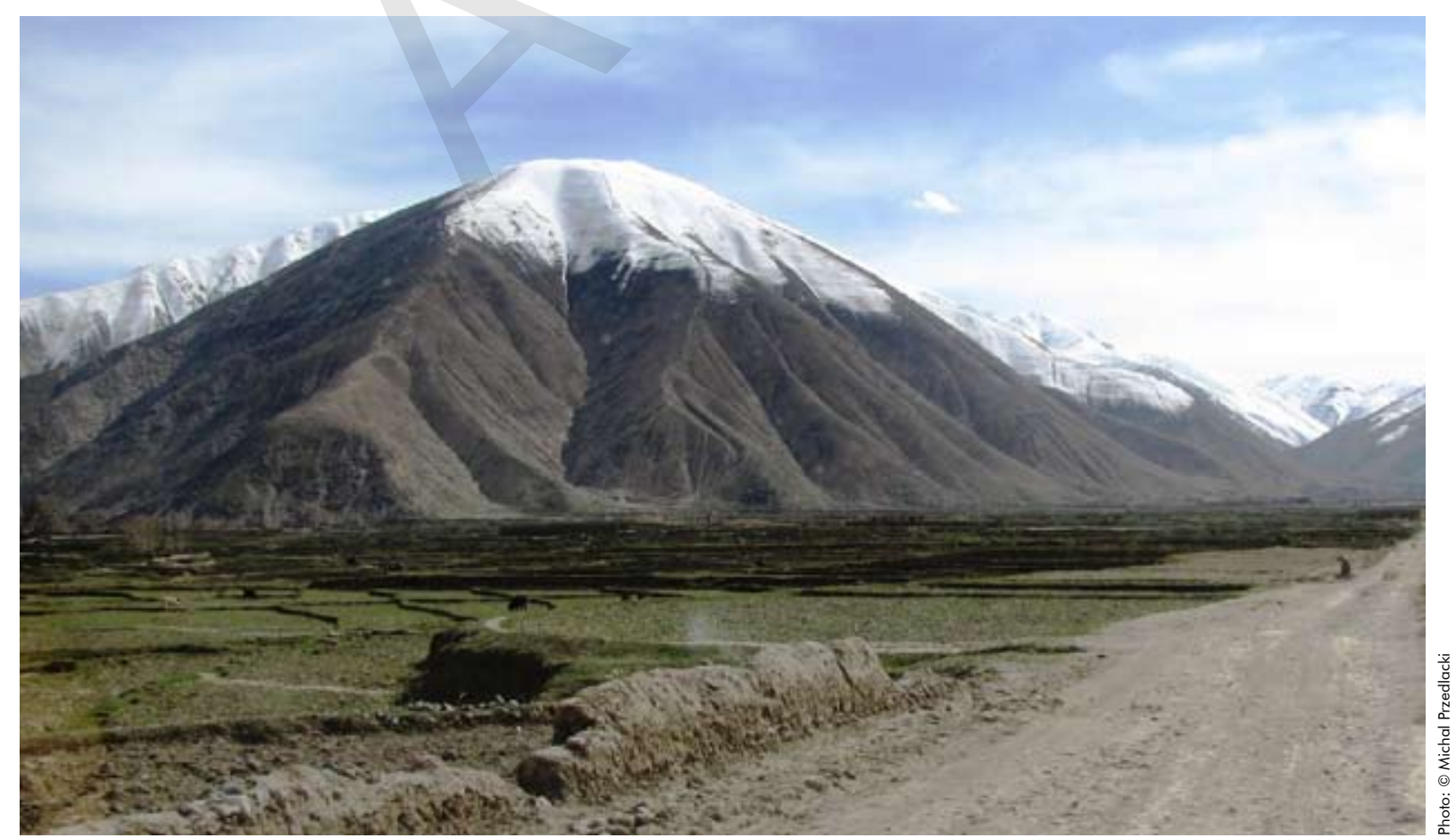




\begin{tabular}{|c|c|c|c|c|c|c|c|}
\hline Hazard & Narrative & Impacts & $\begin{array}{l}\text { Loss } \\
\text { of life }\end{array}$ & Duration & $\begin{array}{l}\text { Spatial } \\
\text { extent } \\
\left(\mathrm{km}^{2}\right)\end{array}$ & $\begin{array}{l}\text { Fre- } \\
\text { quency }\end{array}$ & $\begin{array}{l}\text { Ten- } \\
\text { dency }\end{array}$ \\
\hline $\begin{array}{l}\text { Periodic } \\
\text { drought }\end{array}$ & $\begin{array}{l}\text { Decrease in productivity of crops; } \\
\text { forced migration; changese in } \\
\text { livelihood; decrease in amount of } \\
\text { exports; financial losses. }\end{array}$ & 3 & 3 & 4 & 6 & 2 & \\
\hline $\begin{array}{l}\text { Floods due to } \\
\text { untimely and } \\
\text { heavy rainfall }\end{array}$ & $\begin{array}{l}\text { Collapse and sedimentation of irri- } \\
\text { gation canals; destruction of agricul- } \\
\text { tural lands; loss of crops and live- } \\
\text { stock; collapse of dwellings; spread } \\
\text { of epidemic diseases; destruction of } \\
\text { infrastructures such as roads and } \\
\text { bridges; damage to the national } \\
\text { economy. }\end{array}$ & 3 & 3 & 1 & 4 & 3 & $\uparrow$ \\
\hline $\begin{array}{l}\text { Frosts and } \\
\text { cold spells }\end{array}$ & $\begin{array}{l}\text { River levels rise; destruction of river- } \\
\text { side agricultural and non-agricultural } \\
\text { (forest, range, etc.) lands; land } \\
\text { slides; soil erosoin; destruction of } \\
\text { infrastructure such as bridges and } \\
\text { gabions. }\end{array}$ & 3 & 1 & 1 & 5 & 3 & $\uparrow$ \\
\hline $\begin{array}{l}\text { Flooding due } \\
\text { to thawing of } \\
\text { snow and ice }\end{array}$ & $\begin{array}{l}\text { Increase in levels of incidence of dis- } \\
\text { eases that affect humans, agriculture } \\
\text { and livestock; habitat changes affect } \\
\text { wildlife; changes in vegetation cover } \\
\text { and associatied grazing patterns. }\end{array}$ & 3 & 2 & 3 & 5 & 3 & $\uparrow$ \\
\hline $\begin{array}{l}\text { Rise in tem- } \\
\text { perature }\end{array}$ & $\begin{array}{l}\text { Degradation of fruits, crops, vegeta- } \\
\text { ble and health disease, poor econ- } \\
\text { omy and increasing of poverty. }\end{array}$ & 3 & 3 & 3 & 5 & 3 & \\
\hline $\begin{array}{l}\text { Hail, thunder } \\
\text { and lightning }\end{array}$ & $\begin{array}{l}\text { Destruction of crops (particularly hor- } \\
\text { ticultural crops); human and livestock } \\
\text { losses; outflow/gush from floods. }\end{array}$ & 2 & 1 & 1 & 3 & 3 & $\uparrow \uparrow$ \\
\hline $\begin{array}{l}\text { Monsoon } \\
\text { and } 120 \text {-day } \\
\text { winds }\end{array}$ & $\begin{array}{l}\text { Desertification; degradation of agri- } \\
\text { cultural lands and crops; destruction } \\
\text { of infrastructure; air pollution; spread } \\
\text { and transmission of diseases and } \\
\text { respiratory problems; sedimentation } \\
\text { of irrigation systems and springs; } \\
\text { local and national economy nega- } \\
\text { tively affected. }\end{array}$ & 2 & 1 & 3 & 5 & 3 & $\uparrow \uparrow$ \\
\hline
\end{tabular}

1. Impacts: $1=$ US $\$ 1$ per capital; $2=\$ 10 ; 3=\$ 100 ; 4=\$ 1000 ; 5=\$ 10,000$

2. Loss of life: $1=1$ person per event; $2=10$ people; $3=100$ people; $4=1000$ people

3. Duration: $1=1$ day; $2=10$ days; $3=100$ days; $4=1000$ days (more than 1 year)

4. Spatial extent: $1=1 \mathrm{~km}^{2} ; 2=10 \mathrm{~km}^{2} ; 3=100 \mathrm{~km}^{2} ; 4=1000 \mathrm{~km}^{2} ; 5=10,000 \mathrm{~km}^{2} ; 6=100,1000 \mathrm{~km}^{2}$

5. Frequency: $1=1 \%$ probability of occurence in a year; $2=10 \% ; 3=100 \%$ (occurs once a year)

6. Trends: $\uparrow=$ significant increase; $\uparrow \uparrow=$ moderate increase; $?=$ uncertain trend

Figure 4.1: Assessment of climatic hazards (NAPA) 


\begin{tabular}{|c|c|c|c|c|c|c|c|c|}
\hline $\begin{array}{l}\text { Climatic } \\
\text { Hazards }\end{array}$ & Description & $\begin{array}{l}\text { Loss of life } \\
\text { and liveli- } \\
\text { hoods }\end{array}$ & $\begin{array}{l}\text { Human } \\
\text { Health }\end{array}$ & Duration & $\begin{array}{l}\text { Food security and } \\
\text { Agriculture }\end{array}$ & $\begin{array}{l}\text { Environmental } \\
\text { effects (Biological } \\
\text { diversity, forestry) }\end{array}$ & $\begin{array}{l}\text { Water availabil- } \\
\text { ity, quality and } \\
\text { accessibility }\end{array}$ & Trends \\
\hline $\begin{array}{l}\text { Periodic } \\
\text { drought }\end{array}$ & $\begin{array}{l}\text { Decrease in productivity } \\
\text { of crops; forced migra- } \\
\text { tion; changes in livelihoodl } \\
\text { decrease in amount of } \\
\text { exports; financial losses. }\end{array}$ & $\begin{array}{l}\text { Group of live- } \\
\text { stock herders } \\
\text { including } \\
\text { Kuchi, irri- } \\
\text { gated agricul- } \\
\text { turalists and } \\
\text { dryland farm- } \\
\text { ers are affect- } \\
\text { edl around } \\
10,000 \\
\text { casualties per } \\
\text { year of severe } \\
\text { drought. }\end{array}$ & $\begin{array}{l}\text { Malnutrition, } \\
\text { spread of } \\
\text { diseases such } \\
\text { as malaria, } \\
\text { sishnaia, } \\
\text { cholera, } \\
\text { typhoid, tena- } \\
\text { sagenata, } \\
\text { asscarios and } \\
\text { diarrhoea. }\end{array}$ & $\begin{array}{l}\text { Up to } 8 \\
\text { years. }\end{array}$ & $\begin{array}{l}\text { Drough has gener- } \\
\text { ated an estimated } \\
\text { loss of production } \\
\text { of } 75 \% \text { wheat, } 85 \% \\
\text { rice, } 85 \% \text { maize, } \\
50 \% \text { potato and } \\
60 \% \text { of overall farm } \\
\text { production between } \\
1998 \text { and } 2005 \text {. }\end{array}$ & $\begin{array}{l}\text { Pistachio, pine nut, } \\
\text { wild almond and } \\
\text { conifer forest pro- } \\
\text { duction negatively } \\
\text { affected. Waterfowl } \\
\text { sanctuaries such as } \\
\text { Dasht-i-Nawar, Ab- } \\
\text { i-Estada and Kol-i- } \\
\text { Hashmat Khan have } \\
\text { dried up. Wildlife } \\
\text { being displaced. }\end{array}$ & $\begin{array}{l}\text { Decreased avail- } \\
\text { ability of under- } \\
\text { ground water, } \\
\text { springs and } \\
\text { karezes dry up, } \\
\text { flow of major } \\
\text { rivers collapses, } \\
\text { degradation of } \\
\text { watersheds and } \\
\text { drop in level of } \\
\text { water reservoirs } \\
\text { and dams. }\end{array}$ & $\begin{array}{l}\text { Increas- } \\
\text { ing fre- } \\
\text { quency } \\
\text { and } \\
\text { inten- } \\
\text { sity. }\end{array}$ \\
\hline $\begin{array}{l}\text { Floods due } \\
\text { to untimely } \\
\text { and heavy } \\
\text { rain }\end{array}$ & $\begin{array}{l}\text { Collapse and sedimentation } \\
\text { of irrigation canals; destruc- } \\
\text { tion of agricultural lands; loss } \\
\text { of crops and livestock; col- } \\
\text { lapse of dwellings; spread of } \\
\text { epidemic diseases; destruc- } \\
\text { tion of infrastructure such as } \\
\text { roads and bridges; damage } \\
\text { to the national economy. }\end{array}$ & $\begin{array}{l}\text { Approximately } \\
750 \text { casuali- } \\
\text { ties per year. }\end{array}$ & $\begin{array}{l}\text { Increased } \\
\text { incidence } \\
\text { of cholera, } \\
\text { typhoid, diar- } \\
\text { rhoea and } \\
\text { malaria. }\end{array}$ & $\begin{array}{l}3 \\
\text { months }\end{array}$ & $\begin{array}{l}\text { Loss of } 10 \% \text { of agri- } \\
\text { cultural production } \\
\text { and gardens that } \\
\text { are located along- } \\
\text { side rivers and in } \\
\text { high risk areas. }\end{array}$ & $\begin{array}{l}\text { Soil degredation; } \\
\text { loss of natural for- } \\
\text { est (riverine forest } \\
\text { being particularly } \\
\text { affected); increased } \\
\text { levels of water silta- } \\
\text { tion and sedimenta- } \\
\text { tion; displacement } \\
\text { of wildlife. }\end{array}$ & $\begin{array}{l}\text { Infrastructure } \\
\text { damage around } \\
\text { US\$ } 300 \text { million } \\
\text { as a result of a } \\
\text { severe flood. }\end{array}$ & $\begin{array}{l}\text { Increas- } \\
\text { ing fre- } \\
\text { quency } \\
\text { and } \\
\text { inten- } \\
\text { sity. }\end{array}$ \\
\hline $\begin{array}{l}\text { Flooding } \\
\text { due to } \\
\text { thawing of } \\
\text { snow and } \\
\text { ice }\end{array}$ & $\begin{array}{l}\text { River levels rise; destruc- } \\
\text { tion of riverside agricultural } \\
\text { and non-agricultural (for- } \\
\text { est, range, etc.) lands; land } \\
\text { slides; soil erosoin; destruc- } \\
\text { tion of infrastructure such as } \\
\text { bridges and gabions. }\end{array}$ & $\begin{array}{l}\text { Around } 100 \\
\text { casualties per } \\
\text { year. }\end{array}$ & $\begin{array}{l}\text { Increased } \\
\text { incidence } \\
\text { of cholera, } \\
\text { typhoid, diar- } \\
\text { rhoea and } \\
\text { malaria. }\end{array}$ & $\begin{array}{l}4 \\
\text { months }\end{array}$ & $\begin{array}{l}2 \% \text { damage of } \\
\text { agricultural land } \\
\text { alongside rivers }\end{array}$ & $\begin{array}{l}\text { Soil degredation; } \\
\text { loss of natural for- } \\
\text { est (riverine forest } \\
\text { being particularly } \\
\text { affected); increased } \\
\text { levels of water silta- } \\
\text { tion and sedimenta- } \\
\text { tion; displacement } \\
\text { of wildlife. }\end{array}$ & $\begin{array}{l}\text { Destruction of } \\
\text { river banks, } \\
\text { associated agri- } \\
\text { cultural land and } \\
\text { infrastructure at a } \\
\text { value of around } \\
\text { US\$ } 400 \text { million } \\
\text { as a result of a } \\
\text { severe flood. }\end{array}$ & $\begin{array}{l}\text { Increas- } \\
\text { ing fre- } \\
\text { quency. }\end{array}$ \\
\hline $\begin{array}{l}\text { Rise in } \\
\text { tempera- } \\
\text { ture }\end{array}$ & $\begin{array}{l}\text { Increase in levels of inci- } \\
\text { dence of diseases that affect } \\
\text { humans, agriculture and } \\
\text { livestock; habitat changes } \\
\text { affect wildlifel; changes in } \\
\text { vegetation cover and associ- } \\
\text { ated grazing patterns. }\end{array}$ & $\begin{array}{l}\text { Around } 1000 \\
\text { casualties per } \\
\text { year. }\end{array}$ & $\begin{array}{l}\text { Increased } \\
\text { incidence } \\
\text { of malaria, } \\
\text { leshmania, } \\
\text { typhoid, diar- } \\
\text { rhoea. }\end{array}$ & $\begin{array}{l}3 \\
\text { months }\end{array}$ & $\begin{array}{l}\text { Decreased agricul- } \\
\text { tural, livestock and } \\
\text { horticultural pro- } \\
\text { duction. }\end{array}$ & $\begin{array}{l}\text { Less productivity } \\
\text { of natural system, } \\
\text { displacement and } \\
\text { changing of wildlife } \\
\text { habitat. }\end{array}$ & $\begin{array}{l}\text { Increasing eva- } \\
\text { potranspiration } \\
\text { rates; reduction in } \\
\text { water level. }\end{array}$ & $\begin{array}{l}\text { Increas- } \\
\text { ing fre- } \\
\text { quency } \\
\text { and } \\
\text { inten- } \\
\text { sity. }\end{array}$ \\
\hline $\begin{array}{l}\text { Frost and } \\
\text { cold spells }\end{array}$ & $\begin{array}{l}\text { Degredation of fruits, crops, } \\
\text { vegetable and health disease, } \\
\text { poor economy and increas- } \\
\text { ing poverty. }\end{array}$ & $\begin{array}{l}\text { Loss of fruits } \\
\text { and potatoes; } \\
\text { approximately } \\
300 \text { indirect } \\
\text { casualties per } \\
\text { year. }\end{array}$ & $\begin{array}{l}\text { Illnesses asso- } \\
\text { ciated with } \\
\text { cold weather. }\end{array}$ & $\begin{array}{l}3 \text { days, } \\
\text { two } \\
\text { times } \\
\text { per year }\end{array}$ & $\begin{array}{l}20 \% \text { of gardeners } \\
\text { in the country are } \\
\text { affected, particularly } \\
\text { those with horticul- } \\
\text { tural crops. }\end{array}$ & $\begin{array}{l}\text { Affects forest reha- } \\
\text { bilitation and affor- } \\
\text { estation programs } \\
\text { (particularly nurser- } \\
\text { ies and saplings). }\end{array}$ & Low impact & $\begin{array}{l}\text { Increas- } \\
\text { ing fre- } \\
\text { quency } \\
\text { and } \\
\text { inten- } \\
\text { sity. }\end{array}$ \\
\hline $\begin{array}{l}\text { Hail, thun- } \\
\text { der and } \\
\text { lightning }\end{array}$ & $\begin{array}{l}\text { Destruction of crops (par- } \\
\text { ticularly horticultural crops); } \\
\text { human and livestock losses; } \\
\text { oufflow/gush from floods. }\end{array}$ & $\begin{array}{l}\text { Approximately } \\
150 \text { casualties } \\
\text { per year. }\end{array}$ & $\begin{array}{l}\text { Illnesses asso- } \\
\text { ciated with } \\
\text { cold weather. }\end{array}$ & $\begin{array}{l}\text { Around } \\
20 \text { days }\end{array}$ & $\begin{array}{l}\text { Up to } 20 \% \text { loss in } \\
\text { horticultural and } \\
\text { crop production }\end{array}$ & Low impact & Low impact & $\begin{array}{l}\text { Increas- } \\
\text { ing fre- } \\
\text { quency } \\
\text { and } \\
\text { inten- } \\
\text { sity. }\end{array}$ \\
\hline $\begin{array}{l}\text { Monsoon } \\
\text { and } 120- \\
\text { day winds }\end{array}$ & $\begin{array}{l}\text { Desertification; degrada- } \\
\text { tion of agricultural lands } \\
\text { and crops; destruction of } \\
\text { infrastructure; air pollution; } \\
\text { spread and transmission } \\
\text { of diseases and respiratory } \\
\text { problems, sedimentation } \\
\text { of irrigation systems and } \\
\text { springs; local and national } \\
\text { economy negativelyi affected }\end{array}$ & $\begin{array}{l}\text { Around } 10 \\
\text { casualities per } \\
\text { year. }\end{array}$ & $\begin{array}{l}\text { Eyes, respira- } \\
\text { tory and skin } \\
\text { diseases. }\end{array}$ & $\begin{array}{l}120 \\
\text { days }\end{array}$ & $\begin{array}{l}\text { Decrease in horti- } \\
\text { cultural and crop } \\
\text { production, degra- } \\
\text { dation of rangeland } \\
\text { and reduced live- } \\
\text { stock production }\end{array}$ & $\begin{array}{l}\text { Desertification; } \\
\text { decreased plant } \\
\text { cover. }\end{array}$ & $\begin{array}{l}\text { Losses (temporary } \\
\text { and more per- } \\
\text { manent) of infra- } \\
\text { structure, siltation } \\
\text { of water sources, } \\
\text { decreased quality } \\
\text { of water. }\end{array}$ & $\begin{array}{l}\text { Increas- } \\
\text { ing fre- } \\
\text { quency } \\
\text { and } \\
\text { inten- } \\
\text { sity. }\end{array}$ \\
\hline
\end{tabular}

Figure 4.2: Sectoral Impacts of climatic hazards (NAPA) 


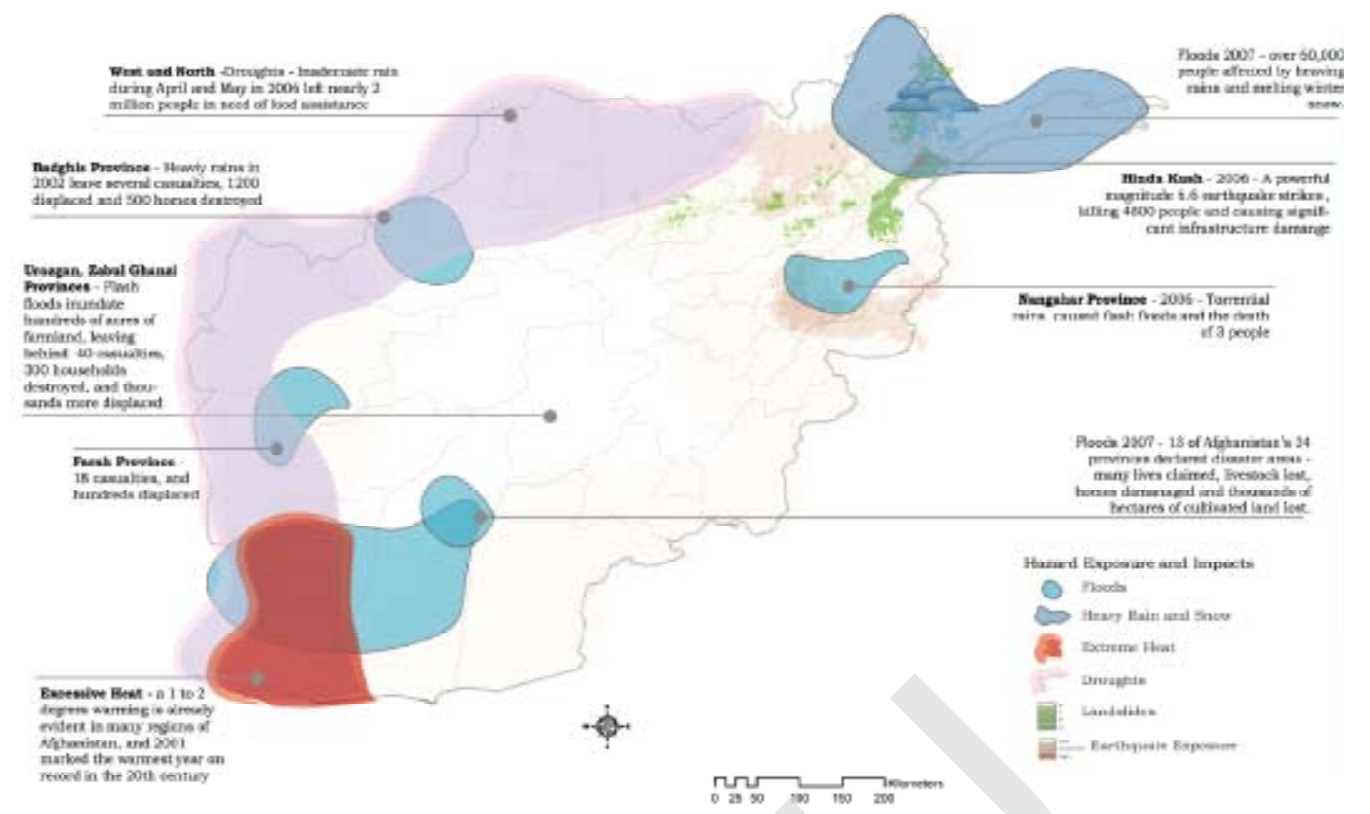

Figure 4.3: Recent climatic hazards in Afghanistan (SEI)

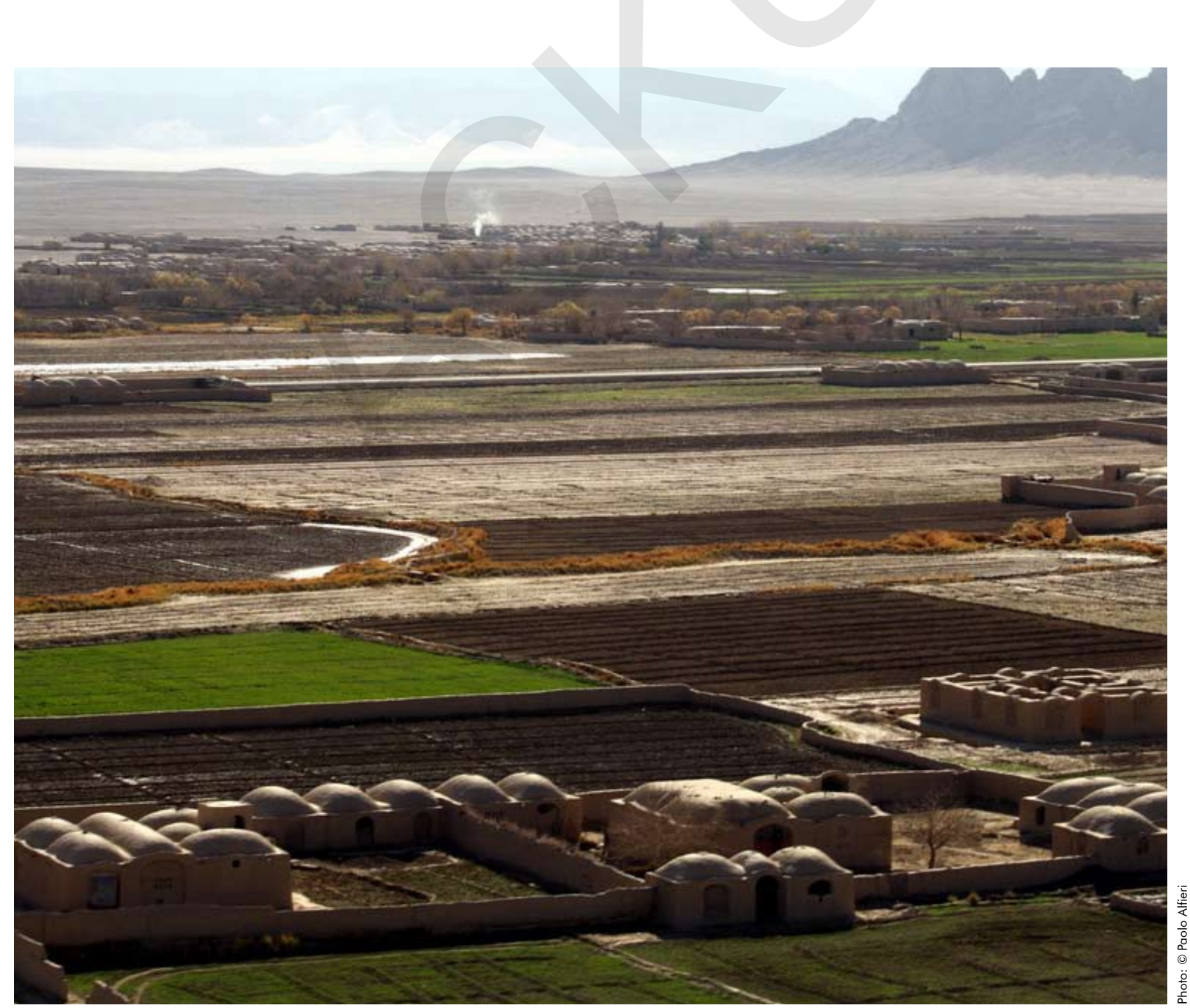




\section{SECTORAL IMPACTS}

The worsening climatic conditions in Afghanistan will continue to impact negatively upon socio-economic development, creating multiple impacts for given sectors. Sectors such as agriculture and water resources are likely to be severely impacted by changes in climate.

The impacts of climate change are numerous and inter-related. Existing climatic stresses on the Afghan economy are likely to intensify over the coming years under the projected climate scenarios. In terms of ecosystem services, soil water content, water from irrigation, firewood and grazing are most affected by the climatic hazards. Agricultural activities in mountain valleys are adversely affected by smaller snow depths leading to less irrigable water, and flash floods from quick thaw associated with increasing spring temperatures. Effects on food crops, market crops and livestock components of livelihood activities are similarly high - to be expected given the importance of these activities to the livelihood portfolio in rural areas of Afghanistan.

In terms of livelihood means, irrigated agriculture, livestock herders and dryland farmers are considered the most susceptible to the impacts of the various climatic hazards. Kuchi pastoralists are considered to be less affected, as their mobile lifestyle has facilitated their adaptation to, and avoidance of, climatic hazards. Climate change, superimposed on poverty, exacerbates existing problems. The NAPA process has undertaken a review of climatic impacts in Afghanistan in relation to a number of sectors. The results are shown in figure 5.1 .

\begin{tabular}{|c|c|c|c|c|c|c|c|c|}
\hline \multirow[b]{2}{*}{ Sector } & \multirow[b]{2}{*}{ Sub-sector } & \multirow[b]{2}{*}{$\begin{array}{l}\text { Socio- } \\
\text { economic } \\
\text { rank }\end{array}$} & \multicolumn{4}{|c|}{ Climatic and climate induced parameters } & \multirow[b]{2}{*}{$\begin{array}{l}\text { Sub-sectoral vulner- } \\
\text { ability index }\end{array}$} & \multirow{2}{*}{$\begin{array}{l}\text { Vulnerability } \\
\text { index }\end{array}$} \\
\hline & & & $\begin{array}{c}\text { Temperature } \\
\text { rise }\end{array}$ & $\begin{array}{l}\text { Eva-transpi- } \\
\text { ration and } \\
\text { salinity }\end{array}$ & $\begin{array}{l}\text { Precipita- } \\
\text { tion pat- } \\
\text { tern ch. }\end{array}$ & Drought & & \\
\hline \multirow{3}{*}{$\begin{array}{l}\text { Water } \\
\text { resources }\end{array}$} & Hydro power generation & 6 & -3 & -4 & -1 & -7 & -90 & \multirow{3}{*}{-333.8} \\
\hline & Underground water & 5.6 & -1 & -2 & -7 & -7 & -95.2 & \\
\hline & Surfact water & 6.4 & -6 & -7 & -3 & -8 & -153.6 & \\
\hline \multirow{4}{*}{ Agriculture } & Wheat and rice production & 8 & 2 & -7 & -3 & -8 & -128 & \multirow{4}{*}{-285.8} \\
\hline & Crop production & 6.4 & 2 & -4 & -2 & -7 & -70.4 & \\
\hline & Livestock husbandry & 6.4 & -2 & -3 & 1 & -6 & -64 & \\
\hline & Fisheries & 2.6 & 1 & -4 & -1 & -5 & -23.4 & \\
\hline \multirow{3}{*}{$\begin{array}{l}\text { Forestry } \\
\text { and range- } \\
\text { land }\end{array}$} & Desertification and soil erosion & 4.6 & -3 & -6 & -3 & -9 & -96.6 & \multirow{3}{*}{-323.4} \\
\hline & Forest and wood production & 6.3 & -3 & -3 & -3 & -5 & -88.2 & \\
\hline & Grassland and forage production & 6.3 & -4 & -7 & -3 & -8 & -138.6 & \\
\hline \multirow{3}{*}{ Biodiversity } & Lake and wetlands & 3.9 & -4 & -6 & 1 & -8 & -66.3 & \multirow{3}{*}{-178.6} \\
\hline & Wildlife and heritage & 4.9 & -4 & -6 & -3 & -6 & -93.1 & \\
\hline & Migration of aquatic species & 1.6 & -2 & -3 & -1 & -6 & -19.2 & \\
\hline \multirow{3}{*}{ Health } & Incidence of tropical diseases & 5.6 & -6 & -2 & -3 & -7 & -100.8 & \multirow{3}{*}{-284} \\
\hline & Diseases affected by disaster & 3.6 & -4 & 1 & -2 & -7 & -43.2 & \\
\hline & Access to fresh water & 5.6 & -5 & -6 & -6 & -8 & -140 & \\
\hline \multirow{3}{*}{ Energy } & Primary energy production & 4.3 & -1 & -1 & 0 & -1 & -12.9 & \multirow{3}{*}{-46.5} \\
\hline & Thermal electricity production & 3.6 & -2 & -1 & -1 & -2 & -21.6 & \\
\hline & Domestic energy demand & 3 & -1 & -1 & 1 & -2 & -12 & \\
\hline \multirow{2}{*}{ Waste } & Liquid waste & 2.5 & -1 & 2 & -1 & 1 & 2.5 & \multirow{2}{*}{-1.4} \\
\hline & Solid waste & 3.9 & -2 & 1 & -1 & 1 & -3.9 & \\
\hline
\end{tabular}

Figure 5.1: Narrative description of climate hazards and assessment of their sectoral impacts (NAPA) 


\section{IMPACTS ON AGRICULTURE AND IRRIGATION}

The vulnerability of the agricultural sector to increased temperatures and changes in rainfall patterns/snow melt is high. Increased soil evaporation, reduced river flow from earlier snow melt, and less frequent rain during peak cultivation seasons will all impact upon agricultural productivity and crop choice availability. Crop failure levels due to water shortages and the amount of potentially productive land left uncultivated will likely increase. More water intensive staple crops will become less attractive to farmers, with a likely increase in the attractiveness of those that are more drought hardy, including opium poppy. By 2060, large parts of the agricultural economy are likely to have become marginal without significant investment in water management and irrigation. The existing irrigation system is operating at a low efficiency rate of about 25 per cent, which indicates that there is considerable scope for reducing wastage of water.

Agriculture is the largest economic sector in the country and is expected to remain so in the medium term. In recent years it has represented one third to one half of the total GDP and 50-80 per cent of the work force. About 85 per cent of the Afghan population is either directly or indirectly dependent on agriculture for their livelihoods. The estimated national farming population is 12.1 million while the non farming rural population is only 2.5 million. Although the relative importance of agriculture is expected to decline with economic development, the sector will continue to increase in absolute size and presents the main focus for economic recovery, poverty reduction and poppy eradication.

There are strong regional differences in Afghanistan, based on geological features that determine sources of water (Karez canal system in the south and springs in the north), and variations in altitude, climate, and vegetation. Two basic farming patterns exist: a mixed crop and livestock system, and the Kuchi pastoral system. The latter is based on a nomadic existence, named after the Kuchi communities who undertake a seasonal migration and transfer of grazing animals to different pastures.

It is estimated that between 12-15 per cent of the total area of Afghanistan is suitable for cultivation (either irrigated or rain fed). There has been a mean annual decline of 3.5 per cent of agricultural production since 1978 , equating to a loss of 30 per cent of agricultural land and pastures through degradation or abandonment. It is estimated that only 6 per cent of cultivatable land is now productive. This could be doubled. Afghan pastures are generally located in the lower valleys and steppes which have been affected by soil erosion and land mines. Growing urban centres have encroached upon fertile agricultural land, and important wetlands have been drained for urban expansion. More than 80 per cent of the land could be subject to soil erosion. Tectonic activity, irregular rainfall events and friable soils contribute to erosive processes.

More than half of all irrigated arable land lies north of the main Hindu Kush range in the drainage systems of the Amu Darya River. Much of the remaining irrigated land lies in the river basins draining southwest, west and southeast out from the central massif, most significantly the basin of the Helmand River system. Although estimates vary, it is thought that about 3.3 million ha (5 per cent of the total land area) is irrigated and regularly cropped, while 4.5 million ha ( 7 per cent) is rain-fed and is cropped opportunistically, depending on precipitation. With the increasing population and the return of refugees, the agriculture resource base is under considerable stress. Increasing population pressure on available land over the last two to three generations has led to expansion of rain-fed wheat crops into traditional grazing land and high mountains.

Agriculture accounts for 95 per cent of water consumption. The estimated area of land under irrigation is 3 million ha (approximately 5 per cent of total land area). Of this, only ten per cent is being irrigated using properly engineered systems with the remainder dependent on traditional irrigation methods, some of these based on run-offs from or use of aquifers that are being degraded by deep water wells and insufficient investment in recharge basins. This is a clear example of short-sighted development leading to maladaptation. The existing irrigation system is operating at a low efficiency rate of about 25 per cent, which indicates that there is considerable scope for reducing wastage of water. Power asymmetries have led to water rights infringements at the head of irrigation systems often leading to abandonment of villages lower down. Much of Afghanistan's irrigated land does not receive sufficient water to ensure cropping for all seasons and NRVA 2005 indicates that 8 per cent of irrigated land lies either fallow or uncultivated. Significant donor funded investment has gone into rehabilitating damaged or degraded irrigation systems, but little has been done in terms of making new investments in the structures needed to increase efficiency in water use, such as storage, canals and water harvesting.

Despite significant snowfall and melt, topography limits the options to harness and distribute the available water. 


\begin{tabular}{lll}
\hline Categories & $\%$ & Number weighted observations \\
\hline Kuchi & 55 & 12,210 \\
\hline National & 74 & $1,311,682$ \\
\hline Rural & 74 & $1,279,311$ \\
\hline Urban & 65 & 20,161 \\
\hline
\end{tabular}

Figure 5.2: Irrigated land among those engaged in agriculture (source NRVA)

In 1979, sheep numbers were estimated to be about 14 million and goat numbers at three million. Numbers fell dramatically during the ten years of Soviet war, according to some estimates by as much as 40 per cent. In the ten years after 1989, a period of comparative rural peace and good grazing led to sheep numbers rising to an estimated 24 million and goat numbers to nine million. Persistent drought and poor grazing since 1998 again reduced flock numbers. However, relatively good rainfall in 2006/2007, together with improved quality and quantity of pasture, has led to a reversal of this trend.

The nomadic/ transhumant kuchis are mainly ethnic Pashtun (but also include Dari speaking groups of Arab descent and Gujor groups). They can be broadly grouped into two types of kuchi: 1) transboundary kuchis or Kuchian Obori who migrate into neighbouring Pakistan for the winter; and 2) transhumant kuchis or Kuchian Dawragard who migrate within the country; to the south and west in the winter and to the north and north-east in the summer. Collectively they own about one-third of the national flock. Typically flocks are comprised of 80 per cent sheep and 20 per cent goats, with horses, donkeys and camels used for transport and their traditional homes being black goat-hair tents. The loss of pastures has severely affected Afghan nomads, causing mass migration into Mazar and Herat. Many of the Pashtun Kuchis winter in Pakistan as far south as the southern Punjab and the Sind, moving back to Afghanistan in the spring and gradually into the high mountains to $3,000 \mathrm{~m}$ altitude and above in the summer as the snow recedes. Their mobility has facilitated their adaptation to climate change, although the degree to which this is the case is being increasingly limited by other socio-economic factors that include disruption of traditional migration routes, conflict, and increased competition with comparatively sedentary livestock herders.

Farm sizes are often very small. Many farmers remain food insecure with risky livelihoods; most farmers are not self sufficient in any food type with about 61 per cent relying on off farm incomes. Approximately 60 per cent of farmers are estimated to be in debt. There is a very high household expenditure on food (75-85 per cent) this year up from 40 per cent in 2005 . These factors have contributed to increased risk of food insecurity and malnutrition. Response strategies have included reduction in food quality and quantities, purchasing on credit and reduced discretionary expenditure.

Opium poppy is the most important agricultural crop in Afghanistan. The Afghan Opium Survey for 2007 found that net opium poppy cultivation, after eradication, had risen by 17 per cent from 2006 to cover 193,000 hectares of land. While the number of poppy-free provinces has increased from six to 13 over the same period, the number of people involved in opium production has also risen - from 2.9 million to 3.3 million, or 14.3 per cent of Afghanistan's total population. In 2006, poppy cultivation also rose (with estimates of an increase of 60 per cent as compared to 2005), largely as a result of the insurgency and the resulting insecurity. Afghanistan is currently a world leader in the production of illegal opium ( 90 per cent of global production). In 2006 opium production was estimated at approximately 6,100 tons, worth around US\$ 3.1 billion or almost 50 per cent of Afghanistan's legal GDP. The Afghan economy is therefore far more dependent on the production, refinement, and export of narcotics than any other in the world with the per capita income from narcotics exceeding official development assistance.

Cereal production is the key non-opium agricultural sector for Afghanistan. Domestic production has suffered over recent years, partly due to export restrictions to neighbouring countries such as Pakistan, and high levels of cereal imports from Pakistan, Kazakhstan, Uzbekistan and Iran, but in large part due to lower than trend production resulting from poor rains and snows. Most Afghan farmers are currently not self sufficient in cereal production even in good years.

The vulnerability of the agricultural sector to increased temperatures and changes in rainfall patterns and snow melt is considered to be high. Increased soil evaporation, reduced river flow from earlier snow melt, and less frequent rain during peak cultivation seasons will all impact upon agricultural productivity and crop choice availability. 
This has been evident over the last decade during a prolonged period of drought where poor harvests and crop failures have been accompanied by a falling water table. Significant areas of potentially productive land are now uncultivated due to lack of available water and this trend is set to continue. The lack of water has the potential to decrease the attractiveness of more water intensive crops and increase those that are drought hardy, such as opium poppy.

Livestock numbers are estimated to have been reduced by 50 per cent during this period due to outward migration and starvation. The effects of environmental degradation and lower agricultural output reduce the availability of animal feed, and the funds available for livestock husbandry. This is especially true for the more vulnerable Kuchi nomadic group.

Reduced agricultural and pastoral productivity has the potential to impact heavily on livelihoods and distribution effects are greatest for the poorest and most vulnerable. Impacts on human health, like increased prevalence of disease affect labour available for agriculture and other non-farm rural economic activities.

\section{IMPACTS ON WATER RESOURCES}

The cumulative effects of more frequent and intense droughts on reservoirs and groundwater could threaten the water supply of entire communities in the most arid regions of Afghanistan, leading to a range of humanitarian crises, including disease, population displacement and conflict. Rises in winter and spring temperatures will lead to more rapid and earlier snow melt, creating risk of flash flooding. The impact of increasingly frequent flash floods is exacerbated by drought, which has the effect of hardening soils and reducing their permeability. The lack of water availability will increase pressure on Afghanistan and surrounding states to claim the greatest possible share of regional water sources in the longer term. Water disputes have plagued the central Asian region for years and will likely continue if climate change increases water scarcity in the region. Efforts by Afghanistan to increase its share of water use in the region may have regional implications.

The management of water is crucial to Afghanistan's future productivity. It covers a broad range of uses including irrigation for agricultural output, use in hydropower generation and in health management through the provision of clean and accessible community water supplies. The water sector has been severely affected by 24 years of war. The destruction and collapse of the existing water infrastructures due to lack of maintenance are considerable. Rural life and traditional water rights, rules and regulation systems like water management have been highly disrupted as well.

However, there is a lack of resources needed to improve water management, including a lack of skilled human resources. Information systems are now being reconstituted, but there is a lack of reliable hydrological, meteorological, geotechnical and water quality data. The infrastructure and equipment needed to efficiently conserve and utilize water resources is insufficient. There are limited data on ground water resources and information indicating that un-regulated deep well drilling may be depleting aquifers that are essential to water supplies and traditional irrigation systems (Karezes and springs). There is a lack of economic mechanisms regulating water use and investments for water supply, sanitary systems, irrigation, and hydropower generation.

Climate change is making water resources scarcer in Afghanistan. This became particularly apparent during the recent years of drought, and development efforts are struggling to keep up with the challenges. Cumulative effects of more frequent and intense droughts on reservoirs and groundwater could threaten the water supply of entire communities in the most arid regions of Afghanistan, leading to a range of humanitarian crises, including hunger, disease, population displacement and conflict.

Rises in temperature will lead to more rapid and earlier spring snow melt, creating risk of flash flooding. The impact of increasingly frequent flash floods is exacerbated by drought, which has the effect of hardening soils and reducing their permeability.

Water shortages from changes in snow-melt and droughts will increase pressure on Afghanistan to claim the greatest possible share of regional water sources in the medium term. Water disputes have plagued central Asian countries for years and will likely continue if climate change furthers water scarcity in the region. Any efforts by Afghanistan to increase its share of water use in the region may have regional security or diplomatic implications. 


\section{IMPACTS UPON LIVELIHOODS AND SOCIAL PROTECTION}

The poor are most vulnerable to the effects of climate change in Afghanistan. Climate change is likely to compound existing food security issues and impact heavily upon those dependent on the agricultural economy, making achieving the Millennium Development Goals more difficult by 2020. The distributional effects are more likely to fall upon women and children, and upon those involved in subsistence agriculture or pastoralism. A large proportion of the Afghan population live just above the poverty line and are highly vulnerable to climatic shocks. Climate change has the potential to tip a large percentage of population into poverty. Impacts on human health, such as increased prevalence of disease, affect labour available for agriculture and other non-farm rural economic activities. The effects of environmental degradation and lower agricultural output reduce the availability of animal feed, and the funds available for livestock husbandry.

The Afghan population is defined by a high level of poverty and social vulnerability. Approximately forty per cent (or twelve million) people are estimated to live below the poverty line with per capita incomes of about US\$14 per month. Food poverty is estimated to be even bigger: around forty five per cent of the Afghan population unable to purchase a basic food basket to provide 2100 calories consumption per day.

Climatic shocks pose the greatest threat to poor populations. The goal of eradicating extreme hunger and poverty by 2020 as per Millennium Development Goals in Afghanistan could be severely hampered by climate change. In its Fourth Assessment Report, the IPCC indicated that the severity of climate change impacts depends not only on changes in temperature and precipitation patterns but on a host of other factors related to the various dimensions of poverty. Human development impacts are generally exaggerated where climate patterns interact with pre-existing social and economic vulnerabilities.

While households and communities in Afghanistan have been adapting to climate variability for a long time, the country is currently maladapted to current and future climate risks. Poor communities in Afghanistan are already highly vulnerable to climate risks as most recently evidenced by the springtime flooding events and recurrent drought episodes. The poorest communities (e.g., small farmers, livestock herders) will likely experience the greatest vulnerability. These populations are the most exposed and have the least means to adapt. This pattern is already transforming today's climate extremes in Afghanistan into increasingly catastrophic events requiring disaster relief.

The most vulnerable members and the degree of the impact vary according to ethnic group. Poverty is more widespread among the rural poor and Kuchis. More than 75 per cent of the population live in rural locations and are dependent on natural resources and ecosystem services. There are differences in poverty levels between rural (36 per cent) and urban (21 per cent) communities. However, latest studies on urban livelihoods indicate rising poverty among the urban poor.

Women and children are extremely vulnerable to climate related socio-economic impacts. Gender inequality is an important characteristic of poverty in Afghanistan. The vast majority of women do not participate in paid economic activities making them highly dependable on their husbands or families. Literacy rates are much lower than for men. During periods of drought, young women and children may be sold into marriage so that their families can afford to eat. Children are also highly vulnerable to climate change, given that they are responsible for small scale livestock herding and firewood collection.

Health is a key issue for poor groups in Afghanistan. The WHO estimated 2.5-3 Million cases of Malaria in 2002 and 85,000 deaths per year from diarrhoea in children under 5 years of age ${ }^{7}$. Climate change will continue to impact upon the spread of food, water, and vectorborne diseases in Afghanistan. Correlations between climate change and disease propagation suggest these trends will worsen in the near- to mid-term (e.g., for Malaria, temperatures of $16-18{ }^{\circ} \mathrm{C}$ are necessary for the parasite to form, and higher temperatures cause faster development $\left.{ }^{8}\right)$. Climate change will undermine Afghanistan's ability to achieve its goals in reducing malaria morbidity and mortality by 50 per cent and 80 per cent within the next 5 years?.

6 Ministry of Public Health (2005) National Malaria Strategic Plan 2006-2010. Available online: http://www.who. int/malaria/docs/complex_emergencies_db/AfghanistanStrategicPlanRBM.pdf

7 WHO (2007) Country Cooperation Strategy: the Islamic State of Afghanistan. Available online: http://www.who. int/countryfocus/cooperation_strategy/ccsbrief_afg_ en.pdf

8 Environmental change and infectious disease workshop (2007) ECDC.

9 Afghanistan National Development Strategy (2008) 
Poor communities, who are more dependent on natural resources and ecosystem services, are particularly sensitive to these changing weather patterns. Beyond those who are classified as poor, there is a significant section of the Afghan population in the agricultural economy (up to 20 per cent) who are only slightly above the poverty line and are extremely vulnerable to climatic shocks. The lack of economic diversification creates dependence on a single highly climatic sensitive sector. Crop failure, reduced yields and stress on livestock will affect the most vulnerable households in the community. It is estimated that the destruction of crops due to droughts represents a higher poverty risk than sickness or loss of a working family member. Poor agricultural performance tends to widen the economic gap between rich and poor.

Drought induced agricultural failure leads to widespread food insecurity and malnutrition with rising food prices. While food insecurity has a number of political and economic causes, climate stress will exacerbate the issue by reducing the agricultural carrying capacity of the land. The most highly affected groups include sedentary farmers, nomads, casual labourers and civil servants as they have no direct access to land and subsistence from it. Food security issues are likely to become more pronounced during the winter and early spring than at present due to overall decrease in food availability after the winter. Despite coping strategies, such as reducing food quantity and quality intake, purchasing food on credit or using loans from friends and reduced discretionary expenditure it is estimated that 35 per cent of the population do not meet their minimal daily kilocalorie intake and 46 per cent have very poor dietary diversity and very poor dietary consumption. This will increase the dependence on Food Aid and reduce the dietary diversity and consumption of the general population.

Prolonged and more frequent drought episodes may accelerate the process of settlement by the Kuchi population, despite the fact that nomadic pastoralism is a strategy for coping with seasonal climate variation. With the prospect of increasing temperatures, lower, late and poorly dispersed rainfall and thus pressure on alternative livelihoods, such conflicts over land rights look set to increase. The failure of local authorities to deal with disputes over traditional pasture rights has led to number of conflicts and rising poverty among this group.

Figure 5.3 shows the NAPA analysis of sensitivity of livelihood activities and groups to climatic hazards.

\section{IMPACTS ON THE ENERGY SECTOR}

\begin{abstract}
"From a mitigation perspective, greenhouse gas emissions in absolute and per capita terms are extremely low in Afghanistan (0.5 tons $\mathrm{CO}_{2}$ e) and mitigation is not a short term challenge, given that a significant proportion of electricity is generated from both indigenous and imported low-carbon hydropower. Climatic impacts are most likely to be felt in hydro-electricity production, although large thermal power plant and transmission infrastructure are also susceptible to flash flooding and heat stress. Changes in precipitation, ice pack and snow melt patterns, combined with climate change-related land use change (devegetation and increased irrigation) can impact upon the variability and availability of water flow. Smaller hydropower plants (SHP) are particularly vulnerable. Monthly discharge at many lowland hydro plants is already declining, partly due to increased competition for water use from upstream irrigation. Expected impacts of climate change are likely to result in stronger flow peaks in winter (due to higher precipitation and earlier snow melt/deglaciation), and less flow in summer, due to lower precipitation, higher evaporation rates and irrigation draw off."
\end{abstract}

The energy sector has suffered considerable damage due to war and operational neglect. The country has never had high rates of electrification. Today it is estimated that 20 per cent of the population have access to public power (grid-supplied) on certain days for a limited number of hours. Nationally seven grids distribute power, with supply coming from domestic hydro generation; imported power and thermal generation. Isolated diesel generation has dramatically increased since 2002 and will continue to play a large role in power supplies. Rural populations use local waste, solar panels, batteries and small wood, coal, kerosene supplies for basic cooking and heat.

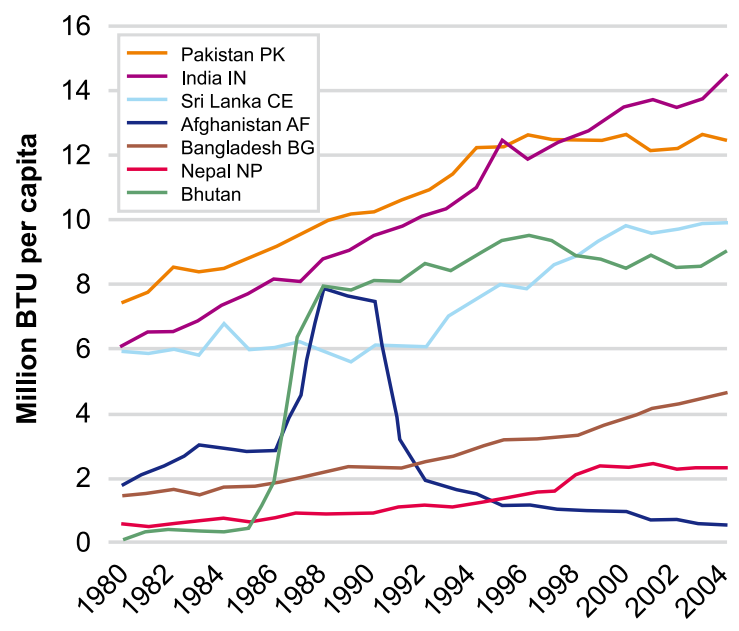




\begin{tabular}{|c|c|c|c|c|c|c|c|c|c|c|}
\hline & \multicolumn{7}{|c|}{ Climatic Hazards } & \multirow[b]{2}{*}{$\begin{array}{l}\text { Pre- } \\
\text { liminary } \\
\text { exposure } \\
\text { index }\end{array}$} & \multirow{2}{*}{$\begin{array}{l}\text { Weight- } \\
\text { ing - area } \\
\text { affected } \\
\text { / impor- } \\
\text { tance }\end{array}$} & \multirow[b]{2}{*}{$\begin{array}{l}\text { Final } \\
\text { score }\end{array}$} \\
\hline & $\begin{array}{l}\text { Periodic } \\
\text { drought }\end{array}$ & $\begin{array}{l}\text { Floods due } \\
\text { to untimely } \\
\text { and heavy } \\
\text { rainfall }\end{array}$ & $\begin{array}{l}\text { Flooding due } \\
\text { to thawing of } \\
\text { snow and ice }\end{array}$ & $\begin{array}{l}\text { Rise in } \\
\text { tempera- } \\
\text { ture }\end{array}$ & $\begin{array}{l}\text { Frost } \\
\text { and cold } \\
\text { spells }\end{array}$ & $\begin{array}{c}\text { Hail, } \\
\text { thunder } \\
\text { and light- } \\
\text { ning }\end{array}$ & $\begin{array}{l}\text { Monsoon } \\
\text { and } 120- \\
\text { day winds }\end{array}$ & & & \\
\hline \multicolumn{11}{|l|}{ Ecosystem services } \\
\hline Soil water content & 5 & 2 & 4 & 4 & 1 & 2 & 3 & 60 & 1 & 60 \\
\hline Water from irrigation & 5 & 3 & 1 & 3 & 1 & 1 & 2 & 46 & 0.8 & 37 \\
\hline Fuelwood & 4 & 3 & 1 & 2 & 1 & 2 & 3 & 46 & 0.8 & 37 \\
\hline Grazing & 5 & 3 & 2 & 4 & 1 & 2 & 3 & 57 & 0.7 & 40 \\
\hline Fodder & 4 & 3 & 2 & 3 & 1 & 3 & 3 & 54 & & 0 \\
\hline Wild fruit production & 4 & 1 & 1 & 3 & 3 & 2 & 2 & 46 & & 0 \\
\hline Wildlife & 4 & 3 & 2 & 4 & 1 & 2 & 2 & 51 & & 0 \\
\hline Medicinal plants & 4 & 3 & 2 & 3 & 1 & 3 & 2 & 51 & 0.4 & 21 \\
\hline Pollination & 4 & 3 & 1 & 1 & 4 & 4 & 3 & 57 & 0.2 & 11 \\
\hline
\end{tabular}

\begin{tabular}{|c|c|c|c|c|c|c|c|c|c|c|}
\hline \multicolumn{11}{|l|}{ Livelihood Activities } \\
\hline Food crops & 4 & 4 & 4 & 3 & 3 & 4 & 3 & 71 & 1 & 71 \\
\hline Market crops & 5 & 4 & 3 & 3 & 5 & 4 & 3 & 77 & 0.5 & 39 \\
\hline Livestock & 5 & 3 & 2 & 4 & 2 & 1 & 2 & 54 & 0.9 & 49 \\
\hline Wood & 4 & 3 & 1 & 2 & 1 & 2 & 3 & 46 & 0.8 & 37 \\
\hline Daily wage labours & 5 & 2 & 1 & 3 & 1 & 1 & 2 & 43 & 0.8 & 34 \\
\hline Useful insects & 5 & 2 & 1 & 4 & 4 & 3 & 4 & 66 & 0.2 & 13 \\
\hline Trade & 4 & 4 & 3 & 3 & 3 & 3 & 2 & 63 & 0.5 & 31 \\
\hline
\end{tabular}

\begin{tabular}{|c|c|c|c|c|c|c|c|c|c|c|}
\hline \multicolumn{11}{|l|}{ Means of livelihood } \\
\hline Dryland farmers & 5 & 4 & 3 & 4 & 1 & 3 & 4 & 69 & 0.7 & 48 \\
\hline Irrigated agriculture farmers & 5 & 4 & 4 & 3 & 4 & 4 & 3 & 77 & 1 & 77 \\
\hline Llvestock herders & 5 & 3 & 3 & 4 & 3 & 3 & 3 & 60 & 0.9 & 54 \\
\hline Pastoralists (Kuchi) & 5 & 4 & 3 & 4 & 1 & 3 & 3 & 66 & 0.5 & 33 \\
\hline Poppy growers & 2 & 3 & 3 & 1 & 3 & 4 & 2 & 51 & 0.8 & 41 \\
\hline Impact index & 89 & 61 & 45 & 62 & 42 & 52 & 53 & & & \\
\hline Weighting - area affected & 1.0 & 0.8 & 0.6 & 0.8 & 0.7 & 0.4 & 0.4 & & & \\
\hline Final score & 89 & 49 & 27 & 50 & 29 & 21 & 21 & & & \\
\hline
\end{tabular}

Figure 5.3: Sensitivity matrix for resources and groups to climate change (NAPA)

Despite Afghanistan having the lowest per capita energy consumption in the South Asia region, demand continues to outstrip supply in every fuel category, including traditional biomass which is unsustainably harvested. The availability of secure energy supplies has been significantly disrupted by conflicts and resulting under-investment over the past two decades. Recent government and donor initiatives have focused on expanding the availability of energy resources throughout the country.
Emphasis has been on expanding and rehabilitating the electricity sector in the major economic hubs of the country and providing basic service in rural areas.

Efforts also have been taken to improve the supply of natural gas, increase availability of hydro-electric generation, rehabilitate and expand electricity transmission distribution systems, develop renewable energy resources in rural and remote areas, increase low-cost power imports and improve the capability of energy sector institutions. 
Afghanistan has significant renewable resources, primarily in the form of hydropower. It is estimated that 23,000 MW of hydropower resources potential are available of which only $260 \mathrm{MW}$ have been so far developed. About 125 sites have been identified for micro-hydro schemes of 100MW potential. In mountainous areas there is sufficient head to make even very low flow streams effective, and glacier-fed streams provide year-round minimum water flow.

Coal is a significant energy resource for Afghanistan. Afghanistan's coal reserves, estimated at over 73 million tons, offer low cost energy and provide energy security for a country that imports over 50 per cent of its power. The Ministry of Energy and Water's Masterplan for 2003-2020 includes an option for a coal power plant. The coal mines identified as sources which can provide coal for such a power plant include Karkar, Ishpushta and the Herat Coal Mines. The operation of coal fired power plant without clean coal or Carbon Capture and Storage will increase Afghanistan's GHG emissions.

Solar PV resource is also good, with high altitudes and approximately 300 days of sunshine a year providing on average 65 kilowatt-hours per square meter per day, and solar thermal devices have practical applications for heating. Wind power potential is high in Heart province, but less strong in other regions. Geothermal applications may also be feasible in the longer term.

Use of sustainable biomass for power generation would require significant reforestation and irrigation efforts. Afghanistan now has only 3 per cent forest or woody shrub land cover and this continues to be deforested for the illegal timber trade in Pakistan and domestic heat and cooking purposes. There have been some small scale efforts to re-establish forests in Afghanistan, for example by USAID. Biogas potentials are currently also quite low, since climatic conditions in most rural areas are harsh, and livestock farming is usually extensive.

Electrical infrastructure in Afghanistan has suffered severely from almost 30 years of war. Blackouts are abundant, power plants are dysfunctional, distribution lines are damaged or lacking and substations are in dangerous conditions. High losses in distribution and transmission reduce the amount of power supplied, which only reaches 6 per cent of the population.

Afghanistan's per capita consumption of electric energy is $21 \mathrm{kWh}$, amongst the lowest worldwide. The country's total generating capacity is at $275 \mathrm{MW}$, of which 180 MW supplies the city of Kabul and its nearly five million inhabitants. The greater Kabul region accounts for about 50 per cent of electricity consumption and has $2 / 3$ of the installed power capacity. Recent developments have focused on the northern power line, creation and repair of regional grids and the rehabilitation of the country's power-generating facilities, mainly large hydropower plants and fossilfuel based installations. Indigenous hydropower is currently delivering about one third of Afghanistan's electric energy supply and this is the main focus on domestic rehabilitation.

There is significant shortage of electricity capacity in Afghanistan. Only 15 per cent of the population currently has access to electricity via the regional power grid. One of the benchmarks of the Afghan Government in the energy sector is to provide 90 per cent of the urban population with electricity by the year 2010 .

An estimated 5-8 per cent is believed to consist of offgrid customers whose power sources derive from solar PV, diesel generators. In remote rural areas, off-grid and mini-grid solutions will remain the only feasible mid or even long term solution for the provision of electric energy. Renewable energy, especially mini- and micro-hydropower, is being implemented on various levels throughout the country. Often the demand for power supply is facilitated by the National Solidarity Program, a nationwide fund fostering rural and community development.

Imports are a significant component of current Afghan consumption and are set to grow. To combat the challenge of providing electricity to Afghanistan and meet the benchmarks of the government, a 220 $\mathrm{kV}$ line is currently under construction from the border of Uzbekistan to Puli-Khumri to Kabul. This is expected to be completed in 2009, and will have a $300 \mathrm{MW}$ of power, although only $75 \mathrm{MW}$ is expected to be available for import. A $220 \mathrm{kV}$ line is also being planned from the border of Tajikistan to Puli-Khumri which will then connect to Kabul. Furthermore, Turkmenistan has expressed interest in exporting its excess power (estimated at 1,000 MW) through a 500 $\mathrm{kV}$ transmission line which if constructed would also connect at Puli- Khumri. Additional imports from Tajikistan and Turkmenistan will require significant investment and time to complete. The expected imported power from Uzbekistan is not enough to meet the needs of Kabul, which according to the current population's needs is at least $500 \mathrm{MW}$. There are political risks in becoming too reliant on imported power from the Central Asian Republics. Alongside hydro, coal provides an attractive and reliable indigenous energy source. 


\begin{tabular}{llll}
\hline Location & Output & Stage & Donor \\
\hline Naghlu & $100 \mathrm{MW}$ & In Progress & World Bank \\
\hline Mahupar & $66 \mathrm{MW}$ & In Progress & $\mathrm{KfW}$ \\
\hline Sarobi & $22 \mathrm{MW}$ & In Progress & $\mathrm{KfW}$ \\
\hline Kajakai & $33 \mathrm{MW}$ & Feasibility & USAID \\
\hline Darunta & $11.5 \mathrm{MW}$ & Feasibility & USAID \\
\hline Salma & $42 \mathrm{MW}$ & Completion & India \\
\hline
\end{tabular}

Figure 5.4: Large hydropower plants rehabilitation projects; source: AEIC, 2006a

Electricity continues to be subsidized by the state, with utilities failing to collect monies owed, and poor billing and metering systems. This results in lack of funds to meet both operating and capital investment requirements. Combined losses and subsidies are costing the Government \$128.5 million annually. Given that infrastructure investments are growing and increasingly more power is being produced, unless radical changes take place, losses will steadily climb. These losses are not only a drain on the power system. They represent resources that could be going to produce more energy or to other development needs. It is clear that changing this must be a top priority in the electricity sector.

\section{Energy related GHG emissions and mitigation opportunities}

currently afghanistan contributes little to global emissions. The Asian Development Bank has undertaken an initial emissions inventory. Total $\mathrm{CO}_{2}$ emissions are estimated at $12 \mathrm{~m}$ tonnes pa, resulting in a per capita rate of approximately 0.5 tonnes pa, although current population statistics are unreliable. This compares to annual per capita emissions of 40 tons in the UAE, 20 tonnes in the United States and 10 tonnes in the United Kingdom. The most significant sources of $\mathrm{CO}_{2}$ emissions arise from the energy sector and Land Use Change and Forestry. $\mathrm{CH}_{4}$ emissions arise primarily from the energy and agricultural sectors. These sectors therefore offer the greatest focus for both mitigation and adaptation responses. National Emissions are set to grow under development and population growth paths. According to the UN, the population of Afghanistan in 2003 was at about 24 million with an annual population growth rate for 2000-2005 of about 3.9 per cent, one of highest in the world. The projected population for the year 2015 is about 35 million and, in the absence of embarking on a clean energy development path, suggests correspondingly higher levels of GHG emissions over time.

Renewable projects will have significant carbon reduction potential, potentially allowing Afghanistan to access finance streams from global carbon markets. In a study conducted in Afghanistan by ADB, it is estimated that generation of one megawatt hydroelectricity would lead to an annual $\mathrm{CO}_{2}$ emission reduction of 2,380 tons. Hence, there is some potential for Afghanistan to develop CDM projects and attract external financing from the international market.

In order to be eligible for CDM credits for development of these projects, Afghanistan should be a party to the United Nations Framework Convention on Climate Change (UNFCCC) Kyoto Protocol. In addition, Afghanistan should establish a Designated National Authority (DNA) to coordinate the CDM approval process on the national and international level on behalf of the government. Though, Afghanistan signed the UNFCCC on 12 June 1992 as a Non-Annex I Party to the Convention (ratification took place on 19th September 2002), it is yet to sign the Kyoto Protocol, and is therefore unable to become a CDM host country. Also, Afghanistan has not established a DNA, and is thus noncompliant to the second formal requirement for hosting CDM projects. An international environmental affairs unit was formed under the Priority Reconstruction Reform (PRR) in June 2006 and this unit could be converted into the DNA.

Climatic Vulnerability of Energy Infrastructure Climate change has the potential to impact on the energy sector. In terms of large thermal power plant and transmission infrastructure, the main threat arises from damage caused by extreme climatic events, such as flash floods or storms.

Hydropower is particularly sensitive to climatic impacts on water. Changes in precipitation, snow layer and melt, and climate related land use change (devegetation and increased irrigation) can impact upon the variability of water flow. Deeply rooted traditional water rights render upstream water management a difficult task for hydro-schemes. For example, in the case of Chak-e-Wardak power plant, part of flow loss is due to increasing irrigation demands. 
Smaller hydropower plants (SHP) are particularly vulnerable. Most do not include (large) water reservoirs, but are mainly run-of-river type, and are especially sensitive to variations in river-flow. If there is only one turbine installed, power-output decreases disproportionately with dropping water level, since the loss of efficiency of the turbine cannot be adjusted for by redirecting the flow towards fewer turbines. If peak flow reaches a certain threshold (dependent on features of the turbine-generator system, such as maximum flow and power), the HPP may be switched off to avoid damage. With small installations, this is often done manually. This represents a further potential risk with frequent high-water or flash-floods.

Monthly discharge at many lowland hydro plants is declining, partly due to increased use of water for irrigation upstream. Expected impacts of climate change are likely to result in stronger flow peaks in winter (due to higher precipitation and earlier snow melt/deglaciation), and less flow in Summer, due to lower precipitation, higher evaporation rates and irrigation draw off. This could lead to forced closure of HPPs during both periods. For example, the Mahipar hydroelectric plant is a $66 \mathrm{MW}$ capacity plant that is only operational 2-3 months a year due to low water levels. Of the three hydroelectric power plants that provide electricity to the capital city of Kabul, only one can remain operational year round because of the lack of water flow ${ }^{10}$, a situation that could worsen.

Both effects decrease energy-supply, and trigger conflict between different interest groups. Since the regional water flow varies, site specific assessments would have to be made to determine specific sensitivities. It is clear that climate change impacts have to be taken into consideration for mid- to long-term hydropower planning, since they have the potential to alter the patterns of precipitation and also the buffering function of the glaciers and snow-pack.

The ANDS states that the environmental implications of the expansion of the energy sector will be fully accounted for. These will be both positive, such as reduced pressure for deforestation, while others may be potentially negative, such as increased green house gas emissions. There is great potential for using renewable energy in Afghanistan and some projects are already being piloted.

10 Afghanistan: Energy Overview (2006) Energy Information Administration. Available online: http://www.eia. doe.gov/emeu/cabs/Afghanistan/EnergyOverview.html
Water is therefore an important and vulnerable resource. It is likely that future potential HPP sites will no longer be compatible for hydropower and that existing HPP sites will lose productivity. This would likely lead to or intensify conflicts over water resources, since upstream irrigation also competes with hydropower. A focus on Hydropower in pilot projects could trigger a bias in capacity building measures, causing the MoEW and other institutions to neglect other potential RE sources, regarding them as unreliable even in cases when they may be a considerable option.

One of the key components of the effort to restore infrastructure and fight poverty in the country is the establishment of energy supplies to rural areas. To this day only a small minority of Afghanistan's population (6 to 10 per cent according to various sources) has access to electric energy. Wood and other biomass (animal dung) are the main source of energy for rural communities, supported by polluting diesel generators. Since the degraded environment can't supply sufficient biomass, wood and charcoal are being imported largely from China. The harsh climate demands a high energy supply for heating in winter. Rural households spend up to 30 per cent of their income on nonelectric energy. The use of biomass in heating and cooking also has significant health impacts. Afghanistan should consider diversification of its energy supply during planning process to ensure that negative impacts of water availability on hydropower are kept to a minimum. 


\section{CLIMATE ASSESSMENT OF NATIONAL DEVELOPMENT STRATEGIES}

\begin{abstract}
"At present, climate change is not a consideration in the national or sectoral plans of the Government of Afghanistan (GoA), despite it presenting a significant threat to cross-sectoral development. The phrase 'climate change' is not mentioned in the 2008 version of the ANDS. There are a number of measures contained within the strategies that might be classified as adaptive, but without clear assessments of climate thresholds, they may not be sufficient for the increased severity and frequency of impacts. Nowhere are these impacts analysed in the context of a larger process. Climate Risk Screening Approaches are required to ensure that project activities implemented under the strategies lead to beneficial adaptation outcomes".
\end{abstract}

This section provides a brief review of the existing national development strategies to assess to what extent future climate change been internalised in the strategy planning process from both an adaptation and mitigation perspective. It focuses upon the four strategy areas that are likely to be most impacted by climatic change, both from an adaptation and a mitigation/low carbon growth perspective. Each review has been based on a number of strategy and policy documents, including the 2008 Afghan National Development Strategy (ANDS), the underlying sector strategies and Implementation and Investment Plans where available.

\section{NATIONAL AGRICULTURE AND RURAL DEVELOPMENT STRATEGY}

The ANDS and Agricultural sector strategy do not explicitly recognise climate change as a key issue although drought, alongside civil conflict is cited as a driver behind the reduction in irrigated land. It is clear that it has not yet been mainstreamed in policy making. Nonetheless, the agricultural program strategy contains a number of programmatic elements that respond to existing stresses and support adaptive capacity. Objectives, such as the desire to attract private sector investment to transform agriculture to a high-value commercial sector and a provider of alternative livelihoods are an adaptive strategy for poverty reduction.

The agricultural strategy is to be developed in coordination with a rural development programme to deliver poverty reduction. The Comprehensive Agriculture and Rural Development (CARD) Sector Strategy articulates a road map for the way forward in which poverty reduction through economic regeneration is the central objective. It sets out a series of programs designed to achieve improved quality of life for rural citizens - one in which food security is assured, basic services are provided, incomes increase with households actively engaged in legal activities, employment opportunities expand and where people live in a safe and secured environment. Activities are usefully grouped into two main components: a Comprehensive Agriculture and Rural Development and the Agricultural and Rural Development Zone (ARDZ) initiatives.

\section{NATIONAL SOCIAL PROTECTION STRATEGY}

There is no specific recognition in the sector strategy of the climatic causes of poverty and social vulnerability and migration. These might include drought and lack of access to water, or of the implications of poverty in preventing adaption to increased climatic stress in future.

The strategy for the Social Protection Sector aims to develop the Government's strategic policy framework for the social support, pension reform and disaster preparedness. It complements the Education, Health, Agriculture and Rural Development Sector Strategies, where implementation will be also an important factor in poverty reduction. The population "at risk" includes the chronically poor, vulnerable women and children, the disabled and victims of natural disasters.

The strategy provides significant resources for response to natural disasters, such as drought or floods. Some programs with a climate element are covered in the strategies: For example, the Greening of Afghanistan programme recommends reforestation as a form of public works not only to provide income, but also to reduce soil instability and reduced flood protection. Other goals, such as the phasing out of non-targeted subsides for energy, may encourage a more sustainable energy growth path going forward.

\section{Power Sector Strategy}

There are no formal mitigation or adaptation policies in place in the Power sector strategy. However, there are elements of both in the sector plans. In the short to medium term, the strategy is to meet demand by expanding electricity imports from neighbouring states and by developing indigenous alternatives. Imports are to be sourced primarily from large hydropower facilities. There is a reference to sectoral development 
in an 'environmentally responsible manner' and several references to sustainability, but nothing beyond this. Plans to increase the installed capacity to over $1000 \mathrm{MW}$ by 2012 would also have the benefit of offsetting increased use of expensive and carbon intensive large diesel generators, which are set to fill the supply gap for the coming decade while new facilities are built.

Strategies to develop renewable energy (small hydropower and solar) are included in longer term plans for energy system diversification from 2015, but these are seen primarily in the context of decentralised rural electrification, and increasing access to rural energy services through the promotion of microhydro, solar, waste and small diesel power sources. A sizeable number of small renewable projects have been funded to date, but these have been done under the context of poverty alleviation through MRRD. The development of the power sector is a key precondition for reducing poverty and strengthening private sector and rural development. From an adaptation perspective, the focus on power sector renewal and provision of connections is sensible, to the extent that it will underpin adaptive capability in other parts of the economy, and help diversification away from more climate dependent sectors such as agriculture. Currently, less than 20 per cent of the population have access to intermittent grid power.

From a mitigation perspective, given current development and emissions scenarios, it would seem sensible to set access to energy as the key policy driver, rather than low carbon generation (although the two are not mutually exclusive). The sectoral focus on development of hydropower resources, if implemented, will continue to ensure relatively clean energy mix. Nonetheless, more policy emphasis should be placed on the use of renewables for off grid applications in the context of development. Given the dependence on Hydropower of the Afghan Economy, it seems sensible that modelling work be undertaken and introduced to the strategy on the potential impacts of changes in precipitation, snow pack and river flow on both large and smaller scale HHP. In addition, care should be taken in design and siting of new infrastructure so that the potential for flash floods or increased heat stress is considered.

\section{National Water Resource Sector Strategy}

Neither the ANDS nor the Water Sector strategy makes explicit reference to climate change as a key driver, although drought, alongside civil conflict is cited as an issue in the reduction in irrigated land. Although rehabilitation and repair of existing irrigation and storage structures after years of underinvestment form a key part of the strategy, there are significant elements of integrated water resources management and large scale river basin management that may mitigate against the impacts of climate change on the water sector. The Government will also give high priority to the provision of rural water supply and sanitation projects. In the medium to long-term, the Government will complete hydrological surveys and build new dams with the aim of reclaiming agricultural land.

Nonetheless, proposed policies under the ANDS and associated Water Sector strategy are broadly in line with climate adaptation priorities in terms of building resilience. There is recognition that improving water resource management is central to the productive capacity of the economy and the resilience of the population in terms of poverty reduction, employment and income generation. Water is an input to many productive sectors of Afghanistan; in particular to irrigation agriculture on which food security, rural employment and income generation as well as national income and export earnings depend. With effective and efficient use of water the output from the agricultural sector can still grow significantly.

The strategy seeks to respond to the need to rehabilitate the physical infrastructure that has deteriorated during decades of war and civil unrest, to plan and provide for new infrastructure to be built to cover future demands in water, and to develop capacity and an institutional framework for leading the sector. Within the water resources sector, feasibility studies will be completed and investments will be made in the needed storage facilities, recharge basins, multi-purpose dams, irrigation systems required to improve water sector management for both agricultural and non-agricultural uses. These efforts will augment on-going efforts to rehabilitate and improve management in existing systems. Over time there will be a movement away from a project by project focus on rehabilitation to an Integrated Water Resource Management (IWRM) system geared to the five major river basins in the country, with an eventual devolution of responsibilities down to independent River Basin authorities. 


\section{ADAPTATION AND CLIMATE RISK SCREENING FOR DEVELOPMENT}

\section{ADAPTATION CLASSIFICATIONS}

Adaptation activities that secure the natural resource base, reduce exposure to natural hazards through sustainable agricultural practices, protect water supplies, and diversify livelihood activities will be essential to increasing local resilience in Afghanistan. They may be classified in a number of ways, but one of the most common is autonomous vs. planned adaptation.

- Autonomous adaptation refers to the changes that natural and (most) human systems undergo in response to changing conditions in their immediate environment, irrespective of any broader plan or policy-based decisions. Such adaptation measures do not require centralised management (e.g. policy, research etc.) for their development and implementation and they are often implemented by private households. Such measures are often reactive (after impacts are observed) and happen over the short-medium term. Autonomous adaptation is the reaction of, for example, a farmer to changing precipitation patterns, in that $\mathrm{s} /$ he changes crops or uses different harvest and planting/sowing dates. Afghan pastoralism is a good example of autonomous adaptation. Mobility has evolved to adapt to spatial and temporal variations in rainfall, and in drought years many communities make use of fall-back grazing areas unused in 'normal' dry seasons because of distance, land tenure constraints, animal disease problems or conflict.

- Planned adaptation measures are conscious policy options or response strategies, often multi-sectoral in nature, aimed at altering the adaptive capacity of a system and carried out over the longer term. They are often anticipatory in nature, based on an awareness of imminent change or increasing risk. As such, they are often coordinated by institutional bodies with access to more robust information. Planned agricultural adaptation measures may include deliberate crop selection and distribution strategies across different agroclimatic zones, changes in land-use to maximize yield under new conditions; application of new irrigation technologies. They usually imply major structural changes.

\section{ADAPTATION SCREENING}

Adaptation responses may cover a broad range of activities and interventions. They may range from those focused at reducing the vulnerabilities of populations, to improved planning capacities and targeted responses to specific climate signals. Often, there are a number of potential adaptation options available for a given risk. It is also inevitable that there will be competition between different sectors for limited adaptation funds.

Given a potentially wide range of adaptation options, it is important to employ a methodology to select those options that are liable to create the biggest impact both within and between sectors. While there are no firm rules for doing this, a number of existing frameworks have been developed that can be used to screen adaptation options. These are broadly based on rating systems using the following criteria:

- Coherence with sectoral priorities

- Strength of climate signal and impact

- Political feasibility

- Resource availability

- Cost effectiveness

- Co-benefits to other development aims and programmes (domestic and international)

The NAPA process managed by UNEP and NEPA has undertaken a thorough adaptation screening process to identify key areas and it is not proposed to repeat the exercise here. The climate change working group identified a total of 51 potential activity options for adapting to climate change. These were categorized according to seven broad themes: human health; water resources and renewable energy; agriculture and food security; animal husbandry, grazing and rangelands; forests and biodiversity; natural disaster preparedness and infrastructure; and capacity building. They are listed fully in Annex 5 in the NAPA Climate Change Working Group Report. The NAPA resulted in the identification of a short-list of eleven urgent and immediate adaptation projects. Through a series of evaluation exercises, two adaptation options were short listed and developed into summary project proposals: Improved Water Management and Use Efficiency and 
Land and Water Management at the Watershed Level. Both projects address multidimensional nature of poverty in rural areas, strengthening safety nets and contributing to the ability of rural people to mitigate the impacts of climate change. An overview classification of potential options for water resource management is provided below:

\section{INTEGRATING ONGOING ADAPTATION ACTIVITIES}

Adaptation should not be regarded as a separate and new activity. As identified in the previous section, the current GoA sector strategies include a range of development projects that have a sensible climate adaptation focus or subcomponent without making explicit reference to climate change. Integrating climate risk management to development planning does not necessarily mean inventing totally new projects, but rather applying a more consistent set of criteria to existing project design processes.

The nature of the hazards faced under climate change scenarios will be similar to those already being experienced (although the scale and frequency may increase). As a result, many existing development strategies, technologies, and programmes that have proven to be effective in reducing vulnerability will also be important as strategies for managing climate risks. These include programs such as integrated water resource management and different types of technologies for agricultural production. Indeed, many existing projects have a direct overlap with the list of potential adaptation measures set out in the NAPA report, indicating that significant work is already underway. Figure 7.2 sets out a selection of recent and ongoing programs from the agriculture component of the ANDS that have direct linkages to NAPA adaptation proposals.

While each of these projects may contribute towards building adaptive capacity in the agriculture sector, taken together they reflect a lack of coherent response to climate change in Afghanistan by both GoA and the donor community. Programs continue to be designed and implemented in a piecemeal fashion, often led by individual donor priorities.

\section{CLIMATE RISK SCREENING PROCESS}

Climate risk screening is not explicitly considered for the majority of development investments in Afghanistan at present. This has the potential to result in rapidly rising disaster losses. Where environmental impacts statements (EIS) are undertaken, little attention is given to climatic variability and these are oriented more to compliance than risk reduction. The practice of climate risk assessment in Afghanistan will need to advance in order to keep pace with emerging knowledge of climate forecasts, vulnerability of key systems, and technologies for adaptation.

Effective adaptation policy and programmes need a methodology to account for the increase in the frequency and amplitude of climatic extremes. This is due to, among other things, uncertainty and lack of information. To address this shortcoming, adaptation needs to be integrated in development planning and should initially be based on "noregrets" solutions (dealing with current and future risks simultaneously). Addressing climate risks from the outset is likely to result in investment decisions that increase diversification and reduce vulnerability, though at the cost of potential short-term benefits. Stand-alone adaptation projects should be avoided, but rather be incorporated broader development initiatives. The ultimate goal is for development planning and climatic risk assessment to be inextricably linked.

Risk screening methodologies allow for the integration of climate risks into development planning and would allow both ministries and donors to undertake practical, operational, and strategic measures to align their development objectives with climate change realities.

There are a number of approaches that can be used to screen potential development initiatives to ensure that climate risks are considered from the early stages of project development. It is sensible to undertake a two tier screening process, starting with an initial high-level checklist assessment of potential climate related issues by sector. Where high risk elements are identified, further work can be undertaken to a) understand aspects of a particular project that are directly related to climatic hazards and coping capacity at the community level; b) evaluate the specific effect of project activities on this capacity, and c) determine changes that could be made to improve the projects' effect. The outputs of the tool are specific measures or activities to incorporate into project design.

It is recommended that a sustainable livelihoods framework is used as the basis for more in-depth project or portfolio risk screening. There are four key steps involved in the screening process, as illustrated below. 


\begin{tabular}{|c|c|c|c|c|}
\hline & Flood prone situation & Drought prone situation & $\begin{array}{l}\text { Impaired water } \\
\text { quality }\end{array}$ & Health effects \\
\hline Prevention & $\begin{array}{l}\text { Restriction of urban } \\
\text { development in flood } \\
\text { risk zones } \\
\text { Measures aiming at } \\
\text { maintaining dam safety, } \\
\text { afforestation and other } \\
\text { measures to avoid } \\
\text { mudflows } \\
\text { Construction of dykes } \\
\text { Changes in operation } \\
\text { of reservoirs and lakes } \\
\text { General land-use man- } \\
\text { agement }\end{array}$ & $\begin{array}{l}\text { Reducing need for water } \\
\text { Water conservation meas- } \\
\text { ures/ effective water use } \\
\text { (industrial and other sectors' } \\
\text { practices/technologies) } \\
\text { Water saving (permit systems } \\
\text { for water users) } \\
\text { Improved irrigation efficiency } \\
\text { Land-use management. }\end{array}$ & $\begin{array}{l}\text { Prevention of and } \\
\text { cleaning up of } \\
\text { dump sites in flood } \\
\text { risk zones } \\
\text { Improved waste } \\
\text { water treatment } \\
\text { Regulation of } \\
\text { wastewater dis- } \\
\text { charge } \\
\text { Improved drinking } \\
\text { water intake }\end{array}$ & $\begin{array}{l}\text { Strengthen and } \\
\text { use a capac- } \\
\text { ity for long-term } \\
\text { preparation and } \\
\text { planning, espe- } \\
\text { cially to identify, } \\
\text { address and rem- } \\
\text { edy the underly- } \\
\text { ing social and } \\
\text { environmental } \\
\text { determinants that } \\
\text { increase vulner- } \\
\text { ability }\end{array}$ \\
\hline $\begin{array}{l}\text { Improving } \\
\text { resilience }\end{array}$ & $\begin{array}{l}\text { Operation of reservoirs/ } \\
\text { lakes (surplus of water } \\
\text { can be handled without } \\
\text { causing damage) } \\
\text { Implementation of } \\
\text { retention areas } \\
\text { Improved drainage } \\
\text { possibilities } \\
\text { Structural measures } \\
\text { (temporary dams, } \\
\text { building resilient hous- } \\
\text { ing, modifying transport } \\
\text { infrastructure) } \\
\text { Migration of people } \\
\text { away from high-risk } \\
\text { areas }\end{array}$ & $\begin{array}{l}\text { Enlarging the availability of } \\
\text { water (reservoir capacity) } \\
\text { Improving landscape water } \\
\text { balance } \\
\text { Introduction or strengthening } \\
\text { of a sustainable groundwater } \\
\text { management strategy } \\
\text { Joint operation of water sup- } \\
\text { ply and water management } \\
\text { networks or building of new } \\
\text { networks } \\
\text { Identification and evaluation } \\
\text { of alternative strategic water } \\
\text { resources } \\
\text { Identification and evaluation } \\
\text { of alternative technologi- } \\
\text { cal solutions (desalinization; } \\
\text { reuse) } \\
\text { Increase of storage capacity } \\
\text { both natural and artificial }\end{array}$ & $\begin{array}{l}\text { Safety and effec- } \\
\text { tiveness of waste } \\
\text { water systems } \\
\text { Isolation of dump } \\
\text { sites in flood risk } \\
\text { zones } \\
\text { Temporary waste- } \\
\text { water storage } \\
\text { facilities }\end{array}$ & $\begin{array}{l}\text { Use existing } \\
\text { systems and } \\
\text { links to general } \\
\text { and emergency } \\
\text { response systems } \\
\text { Ensure effective } \\
\text { communication } \\
\text { services for use } \\
\text { by health officials }\end{array}$ \\
\hline Prepc & $\begin{array}{l}\text { Flood warning (incl. } \\
\text { early warning) } \\
\text { Emergency planning } \\
\text { (incl. evacuation) } \\
\text { Flash-flood risks, } \\
\text { (measures taken as pre- } \\
\text { vention, as the warn- } \\
\text { ing time is too short to } \\
\text { react) }\end{array}$ & $\begin{array}{l}\text { prioritization of water use } \\
\text { restrictions for water abstrac- } \\
\text { tion for appointed uses } \\
\text { emergency planning } \\
\text { awareness-raising } \\
\text { risk communication } \\
\text { training and exercise }\end{array}$ & $\begin{array}{l}\text { Restrictions to } \\
\text { wastewater dis- } \\
\text { charge and imple- } \\
\text { mentation of } \\
\text { emergency water } \\
\text { storage }\end{array}$ & $\begin{array}{l}\text { Strengthen the } \\
\text { mechanism for } \\
\text { early warning } \\
\text { and action }\end{array}$ \\
\hline Response & \multicolumn{4}{|c|}{$\begin{array}{l}\text { Emergency medical care } \\
\text { Safe drinking water distribution } \\
\text { Safe sanitation provision } \\
\text { Prioritization and type of distribution (bottled water, plastic bags, etc.) }\end{array}$} \\
\hline covery & \multicolumn{4}{|c|}{$\begin{array}{l}\text { Clean-up activities } \\
\text { Rehabilitation options such as reconstruction of infrastructure } \\
\text { Governance aspects such as legislation on, inter alia, insurance, a clear policy for rehabilitation, } \\
\text { proper institutional settings, rehabilitation plans and capacities, and information collection and } \\
\text { dissemination. }\end{array}$} \\
\hline
\end{tabular}

Figure 7.1: Overview for water sector adaptation measures 
- Understanding climate context: The first step relates to understanding the current and potential future climate impacts and coping strategies, climate hazards and existing coping strategies

- Understanding livelihoods context: Understanding how resource availability (physical, financial, natural) relates to current livelihoods and how they may be impacted by climatic events
- Project Risk Screening: Assess activities in terms of their net effect on important resources related to livelihoods and coping strategies.

- Adjust Project Activities: If the effect is negative, the activity will be flagged for followup in adaptation management planning. Project activities that were identified as having positive or negative impacts on local livelihood resources are reviewed in this step and adjusted as necessary so

\begin{tabular}{|c|c|c|c|c|}
\hline $\begin{array}{l}\text { Programme of } \\
\text { the Agriculture } \\
\text { Sector for ANDS }\end{array}$ & Project & Main area of intervention & Duration & Location \\
\hline \multirow[t]{4}{*}{$\begin{array}{l}\text { Assure food } \\
\text { security for all }\end{array}$} & $\begin{array}{l}\text { Variety and Seed Industry } \\
\text { Development (FAO/EC) }\end{array}$ & New and improved crop varieties; & $2007-2011$ & National \\
\hline & $\begin{array}{l}\text { Alternative agricultural } \\
\text { livelihoods (AALP) Pro- } \\
\text { gramme Phase } 1 \mathrm{FAO} / \\
\text { UK }\end{array}$ & $\begin{array}{l}\text { Development of nationally owed alternative liveli- } \\
\text { hoods strategies and action plans and on farm and } \\
\text { off farm livelihoods diversification opportunities }\end{array}$ & 2005-2007 & National \\
\hline & $\begin{array}{l}\text { Support to vulnerable } \\
\text { populations in drought } \\
\text { affected areas }\end{array}$ & $\begin{array}{l}\text { Provision of improved wheat seed and fertilizer to } \\
\text { over 11,00 vulnerable rural households in selected } \\
\text { areas for the spring and summer planting seasons }\end{array}$ & 2006-2007 & $\begin{array}{l}\text { Selected } \\
\text { provinces }\end{array}$ \\
\hline & $\begin{array}{l}\text { National Agricultural } \\
\text { Experiment Stations } \\
\text { Rehabilitation project } \\
\text { (NARP) JICA }\end{array}$ & $\begin{array}{l}\text { Improved capacity of research. } \\
\text { Appropriate varieties of wheat and vegetable identi- } \\
\text { fied }\end{array}$ & $2005-2010$ & $\begin{array}{l}\text { Selected } \\
\text { provinces }\end{array}$ \\
\hline \multirow{2}{*}{$\begin{array}{l}\text { Manage and } \\
\text { protect the Natu- } \\
\text { ral resource base }\end{array}$} & $\begin{array}{l}\text { PEACE project } \\
\text { USAID/ Texas A and } M\end{array}$ & Early-warning for drought- Kuchi pasture utilization & 2007-2009 & $\begin{array}{l}\text { Selected } \\
\text { provinces }\end{array}$ \\
\hline & $\begin{array}{l}\text { Managing Biodiversity } \\
\text { for Sustainable Food } \\
\text { Security and Nutrition } \\
\text { (FAO/ Germany) }\end{array}$ & $\begin{array}{l}\text { Inventory of local species; promotion of species with } \\
\text { high nutritional or commercial value; environmental } \\
\text { education; technical advice on policy and legislation }\end{array}$ & $2007-2010$ & $\begin{array}{l}\text { Central } \\
\text { level and } \\
\text { selected } \\
\text { provinces }\end{array}$ \\
\hline \multirow{2}{*}{$\begin{array}{l}\text { Improve rural } \\
\text { infrastructures } \\
\text { and irrigation } \\
\text { systems }\end{array}$} & $\begin{array}{l}\text { Accelerated sustainable } \\
\text { agriculture programme } \\
\text { (ASAP/USAID) }\end{array}$ & $\begin{array}{l}\text { Storing and processing of agriculture products, devel- } \\
\text { opment drip irrigation }\end{array}$ & ongoing & $\begin{array}{l}\text { Selected } \\
\text { provinces }\end{array}$ \\
\hline & $\begin{array}{l}\text { Bilateral funded projects: } \\
\text { Iran, India, Italy, Ger- } \\
\text { many, Canada, UN }\end{array}$ & $\begin{array}{l}\text { Cold storage, western basin, water resources man- } \\
\text { agement }\end{array}$ & ongoing & $\begin{array}{l}\text { Selected } \\
\text { provinces }\end{array}$ \\
\hline $\begin{array}{l}\text { Donor funded } \\
\text { project with MAIL } \\
\text { as collaborators }\end{array}$ & $\begin{array}{l}\text { Village-based Watershed } \\
\text { Restoration Program for } \\
\text { Ghor Province } \\
\text { Catholic relief service } \\
\text { (CRS) with funding from } \\
\text { USAID }\end{array}$ & $\begin{array}{l}\text { Reducing water insecurity, in order to produce viable } \\
\text { economic alternatives to poppy cultivation in the Prov- } \\
\text { ince. The objectives project are: } \\
\text { 1. Communities are mobilized around natural } \\
\text { resource management. } \\
2 \text {. Soil and water conservation measures protect key } \\
\text { watershed areas. } \\
\text { 3. Provincial government officials are promoting } \\
\text { watershed restoration in Ghor. }\end{array}$ & ongoing & $\begin{array}{l}\text { Ghor } \\
\text { province }\end{array}$ \\
\hline
\end{tabular}

Figure 7.2: Sample of ANDS projects that overlap with NAPA adaptation priorities 
that opportunities to enhance coping and adaptive capacity are maximized, and risks are minimized

To undertake effective programmatic risk screening, there are a number of recommendations that should be adopted by government ministries:

- Improved governance, including an active civil society and open, transparent, and accountable policy and decision making processes, which can have a critical bearing on the way in which policies and institutions respond to the impact of climatic factors on the poor.

- First steps towards mainstreaming climate issues into all national, sub-national, and sectoral planning processes, such as Poverty Reduction Strategies (PRS) or national strategies for sustainable development.

- Encouraging a ministry with a broad mandate, such as planning or finance, to be fully involved in mainstreaming adaptation.

- Combining approaches at the government and institutional level with bottom-up approaches rooted in regional, national, and local knowledge.

- Empowerment of communities so that they can participate in assessments and feed in their knowledge to provide useful climate-poverty information. They will also need full access to climate relevant information systems.

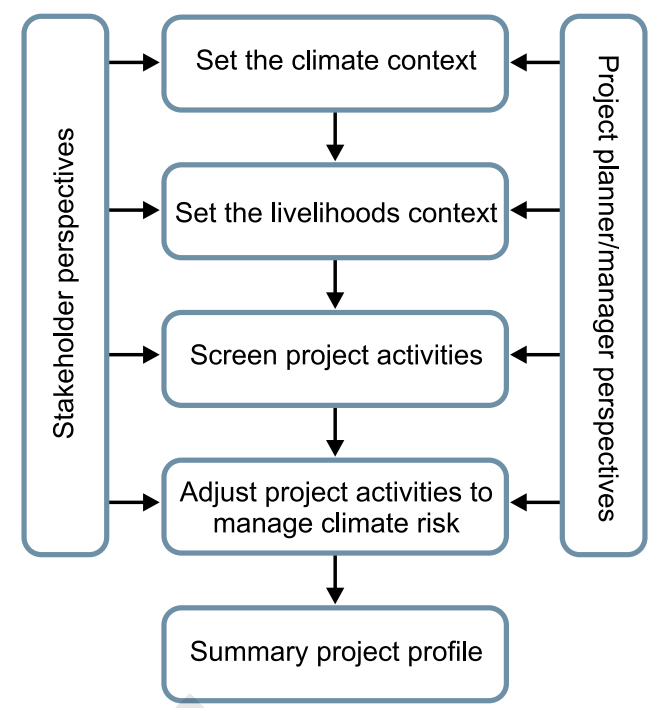

- Finally, climate change needs to be integrated into economic planning. Integration will prevent climate change diverting limited resources into disaster relief and recovery activities and away from long-term development priorities. The national budget process should be the key process to identify climate change risks and to incorporate risk management.

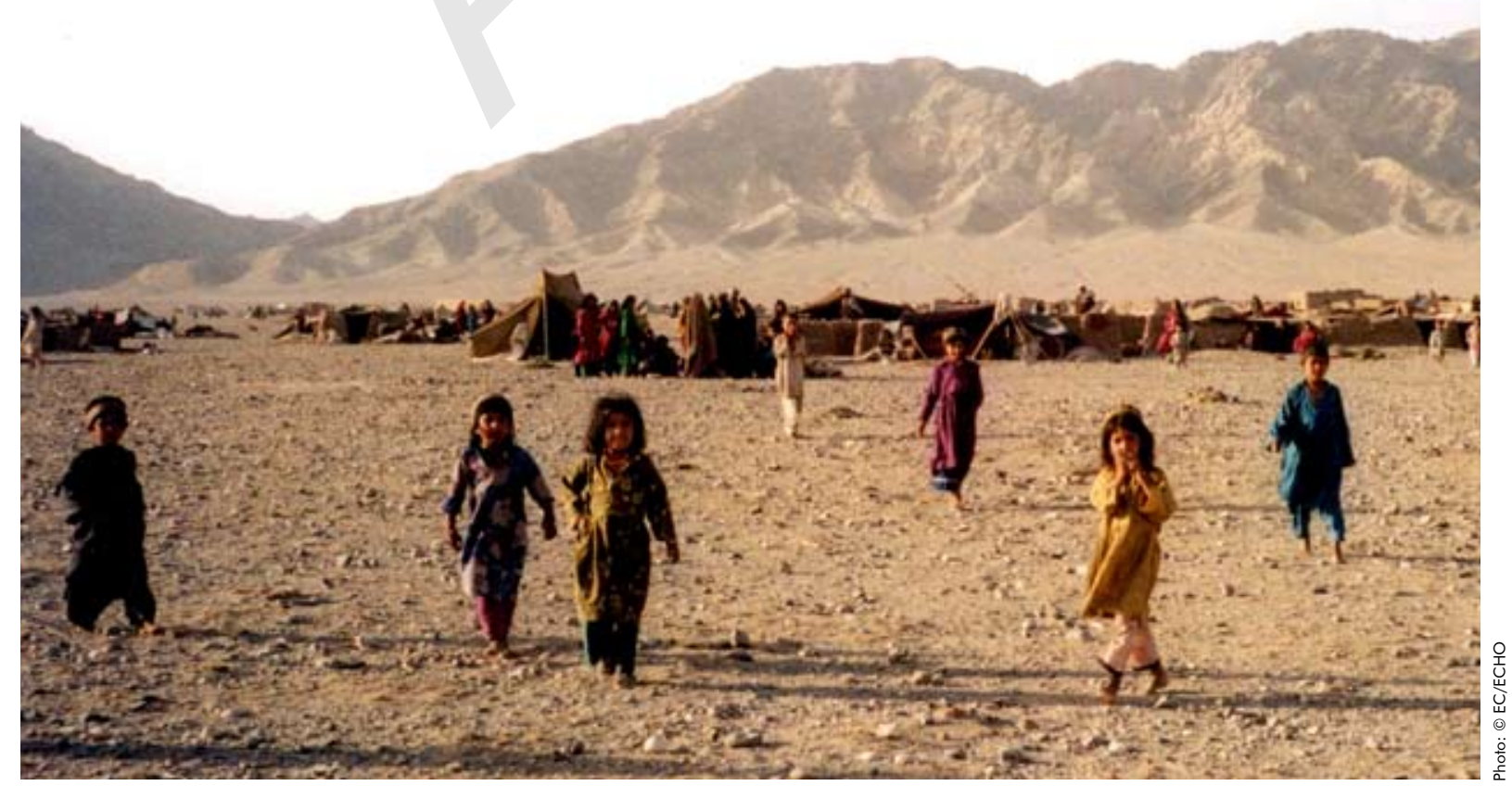




\section{BIBLIOGRAPHY}

AEIC (Afghan Energy Information Center) (2006) Indicative list of Donor Projects http:// www.afghanenergyinformationcenter.org/ pdf/Rehabilitation\%20Programs/Donor\%20 Projects3\%20latest\%20version.pdf.

AEIC (Afghan Energy Information Center) (2006) Geothermal potential in the structural domain of the Hindu Kush in Afghanistan http:// www.afghanenergyinformationcenter.com/ Renewablenergy/geothermaal.htm

Asian Development Bank (ADB) (2003) Rebuilding Afghanistan's Agriculture Sector, South Asia Department, April

Asian Development Bank (ADB) (2006) Country Synthesis Report on Urban Air Quality Management, Afghanistan, Discussion Draft, December 2006, Philippines.

Barnett, T.P., Adam, J.C., and Lettenmaier, D.P. (2005) Potential impacts of a warming climate on water availability in snow-dominated regions. Nature, 438, 303-309.

Burton, I. and Van Aalst, M. (2004) Look Before You Leap: A Risk Management Approach for Incorporating Climate Change Adaptation in World Bank Operations, prepared for the Global Climate Change Team, The World Bank.

Carter, T.R., Parry, M.L., Nishioka, S. and Harasawa, H. (eds.) (1994) Technical Guidelines for Assessing Climate Change Impacts and Adaptations, report of Working Group II of the Intergovernmental Panel on Climate Change.

Christensen, J.H., Hewitson, B., Busuioc, A., Chen, A., Gao, X., Held, I., Jones, R., Kolli, R.K., W.-T., Kwon, W.-T., Laprise, Magaña Rueda, R.,V., Mearns, L., Menéndez, C.G., Räisänen, J., A.Rinke, Sarr, A., and Whetton, P. (2007) Regional Climate Projections, in Climate Change 2007: The Physical Science Basis. Contribution of Working Group I to the Fourth Assessment Report of the Intergovernmental Panel on Climate Change.
Dittberner, H., Sadeeq, M., Frings, U. (2006) Chake-Wardak Small Hydro Power Station, Report 6: Hydrological Data -Report 6.1: Status Report - May, 2006, Afghanistan - German Bilateral Co-Operation, Ministry of Energy and Water Department of Renewable Energy.

FAO (United Nations Food and Agriculture Organization) (2007a.) Representation in Afghanistan, Profiles: river systems, http://www. fao.org/world/afghanistan/prof_rivers_en.htm.

FAO(UnitedNationsFoodandAgricultureOrganization) (2007b.) Representation in Afghanistan, Profiles: ecosystems, http://www.fao.org/world/afghanistan/ prof_nrm_en.htm.

FAO(UnitedNationsFoodandAgricultureOrganization) (2007c.) Representation in Afghanistan, Natural resource management programme, http://www.fao. org/world/afghanistan/proj_nrm_forest_en.htm.

FAO(UnitedNationsFoodandAgricultureOrganization) (2007d.) Representation in Afghanistan, Profiles: North and Northeastern Afghanistan, http://www. fao.org/world/afghanistan/prof_n_en.htm.

GERES (Energies Renouvelables, Environnement et Solidarités) (2007) Les actions de développement durable du GERES en Afghanistan, http://geres. free.fr/fr/pays/afghanistan.php.

Hansen, G. and Fee, E. Wildcard Hydropower? Renewable energy for rural development in Afghanistan vulnerability and adaptation to global change. An assessment conducted by Gerrit Hansen and Eric Fee within the framework of the GTZ project: "Zwischen Hörsaal \& Projekt" University of Applied Sciences Eberswalde (UASE).

Huq, S. and Klein, R., (2003) Adaptation to climate change: why and how, SciDev.Net Climate Change Dossier, policy brief, http:/www.scidev.net/ dossiers/index.cfm?fuseaction=printarticle $\&$ dossier $=4 \&$ policy $=44$.

Ibrekk, H., Stoveland, S, and Ghani, S. (2006) Analysis of the Water Situation in Faryab Province, Afghanistan: Water Resources, Drinking Water, Sanitation and Irrigation, The Royal Norwegian Embassy. 
Klein, R., Dougherty, B., Alam, A., and Rahman, A., (2005) Technology To Understand And Manage Climate Risks, background paper prepared for the UNFCCC Seminar on the Development and Transfer of Environmentally Sound Technologies for Adaptation to Climate Change, Tobago, 14-16 June.

Klein, R., Alam, M., Burton, I., Dougherty, B., Ebi, K., Fernandes, M., Huber-Lee, A., Rahman, A., and Swartz, C. (2006) Applications of Environmentally Sound Technologies for Adaptation to Climate Change, prepared for the UNFCCC Secretariat.

Mansfield, D., (2008) Responding to Risk and Uncertainty: Understanding the Nature of Change in the Rural Livelihoods of Opium Poppy Growing Households in the 2007/08 Growing Season Report for DFID, July 2008.

Ministry of Energy and Water of Afghanistan. 2007. Power Sector Strategy for Afghanistan National Development Strategy. April 2007.

Ministry of Energy and Water of Afghanistan (2007) Water Sector Strategy for Afghanistan National Development Strategy.,April 2007.

Noble, I. (2005) Screening Development Projects for Risks from Climate Change, http://www. climatescience.gov/workshop2005/presentations/ ppt/EC1.6_Noble.ppt.

SAF (2004) Securing Afghanistan's Future: Accomplishments and the strategic path forward, technical annex I: power sector, governmental paper, January 2004.

Smit, B., Pilifosova, O., Burton, I., Challenger, B., Huq, S., Klein, R.J.T., and Yohe, G. (2001) Adaptation to climate change in the context of sustainable development and equity, In Climate Change 2001-Impacts, Adaptation and Vulnerability, J.J. McCarthy, O.F. Canziani, N. Leary, D.J. Dokken and K.S.White (eds.), Contribution of Working Group II to the Third Assessment Report of the Intergovernmental Panel on Climate Change, Cambridge University Press, Cambridge, UK, pp. 877-912.
Sperling, F. and Szekely, F. (2005) Disaster Risk Management in a Changing Climate, discussion Paper prepared for the World Conference on Disaster Reduction on behalf of the Vulnerability and Adaptation Resource Group (VARG).

United Nations Development Programme (UNDP), (2008) Afghanistan Climate Change Country Profiles Afghanistan http://country-profiles.geog. ox.ac.uk.

United Nations Environment Programme (UNEP), (2008a) National Capacity Needs Self-Assessment for Global Environmental Management (NCSA) and National Adaptation Programme of Action for Climate Change (NAPA), September.

United Nations Environment Programme (UNEP), (2008b) Desertification, Rangelands and Water Resources Working Group - Final Thematic Report, September.

USAID (United States Agency for International Development) (2008) USAID/ Afghanistan: Pistachio woodlands rehabilitated. http:// afghanistan.usaid.gov/en/Article.128.aspx.

Van Aalst, M., (2006) Managing Climate Risk: Integrating Adaptation into World Bank Operations, prepared for the World Bank Global Environment Facility Program. 
Institute of Resource Assessment University of Dar es Salaam

P.O. Box 35097, Dar es Salaam Tanzania

Tel: +255-(0)766079061

SEI - Asia

15th Floor Witthyakit Building

254 Chulalongkorn University

Chulalongkorn Soi 64

Phyathai Road Pathumwan

Bangkok 10330

Thailand

Tel: + (66) 22514415

SEI - Oxford

Suite 193

266 Banbury Road,

Oxford, OX2 7DL

UK

Tel: +441865426316

SEI - Stockholm

Kräftriket 2B

SE - 10691 Stockholm

Sweden

Tel: +4686747070

SEI - Tallinn

Lai 34, Box 160

EE - 10502, Tallinn

\section{Estonia}

Tel: +3726276100

SEI - U.S.

11 Curtis Avenue

Somerville, MA 02144

USA

Tel: + $1617627-3786$

SEI - York

University of York

Heslington

York YO10 5DD

UK

Tel: +441904432897

\section{The Stockholm Environment Institute}

SEI is an independent, international research institute. It has been engaged in environment and development issues at local, national, regional and global policy levels for more than a quarter of a century. SEI supports decision making for sustainable development by bridging science and policy.

\section{sei-international.org}

